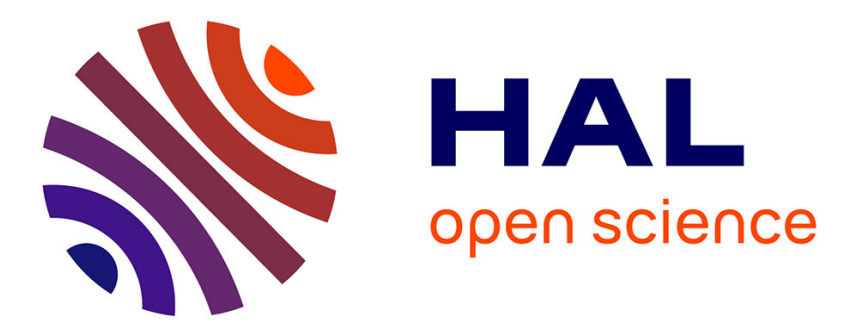

\title{
Numerical modelling of Cretaceous Pyrenean Rifting: The interaction between mantle exhumation and syn-rift salt tectonics
}

Thibault Duretz, Riccardo Asti, Yves Lagabrielle, Jean-Pierre Brun, Anthony Jourdon, Camille Clerc, Benjamin Corre

\section{To cite this version:}

Thibault Duretz, Riccardo Asti, Yves Lagabrielle, Jean-Pierre Brun, Anthony Jourdon, et al.. Numerical modelling of Cretaceous Pyrenean Rifting: The interaction between mantle exhumation and syn-rift salt tectonics. Basin Research, 2020, 32 (4), pp.652-667. 10.1111/bre.12389 . insu-02270635

\section{HAL Id: insu-02270635 \\ https://hal-insu.archives-ouvertes.fr/insu-02270635}

Submitted on 5 Nov 2019

HAL is a multi-disciplinary open access archive for the deposit and dissemination of scientific research documents, whether they are published or not. The documents may come from teaching and research institutions in France or abroad, or from public or private research centers.
L'archive ouverte pluridisciplinaire HAL, est destinée au dépôt et à la diffusion de documents scientifiques de niveau recherche, publiés ou non, émanant des établissements d'enseignement et de recherche français ou étrangers, des laboratoires publics ou privés. 
DR THIBAULT DURETZ (Orcid ID : 0000-0001-8472-7490)

Article type : Original Article

\section{Numerical modeling of Cretaceous Pyrenean Rifting: the interaction between mantle exhumation and syn-rift salt tectonics}

Thibault Duretz ${ }^{1,2}$, Riccardo Asti $^{1}$, Yves Lagabrielle $^{1}$, Jean-Pierre Brun ${ }^{1}$, Anthony Jourdon $^{3}$, Camille Clerc ${ }^{4}$, Benjamin Corre ${ }^{1}$

1. Univ Rennes, CNRS, Géosciences Rennes UMR 6118, F-35000 Rennes, France

2. ISTE, FGSE, University of Lausanne, $\mathrm{CH}-1025$, Lausanne, Switzerland

3. GET, Observatoire Midi Pyrenées, Toulouse, France

4. ISEA, University of New Caledonia, Nouméa, France

Corresponding Author: thibault.duretz@univ-rennes1.fr

\section{Abstract}

The pre-shortening Cretaceous Pyrenean rift is an outstanding geological laboratory to investigate the effects on lithospheric rifting of a pre-rift salt layer at sedimentary base. The occurrence of a pre-rift km-scale layer of evaporites and shales promoted the activation of syn-rift salt tectonics from the onset of rifting. The pre- and syn-rift sediments are locally affected by high-temperature metamorphism related to mantle ascent up to shallow depths during rifting. The thermo-mechanical interaction between décollement along the preexisting salt layer and mantle ascent makes the Cretaceous Pyrenean rifting drastically different from the type of rifting that shaped most Atlantic-type passive margins where salt deposition is syn-rift and gravity-driven salt tectonics has been post-rift. To unravel the dynamic evolution of the Cretaceous Pyrenean rift, we carried out a set of numerical models of lithosphere-scale extension, calibrated using the available geological constraints. Models are used to investigate the effects of a $\mathrm{km}$-scale pre-rift salt layer, located at sedimentary cover base, on the dynamics of rifting. Our results highlight the key role of the décollement layer at cover base that can alone explain both salt tectonics deformation style and high

This article has been accepted for publication and undergone full peer review but has not been through the copyediting, typesetting, pagination and proofreading process, which may lead to differences between this version and the Version of Record. Please cite this article as doi: $10.1111 /$ bre. 12389

This article is protected by copyright. All rights reserved. 
temperature metamorphism of the pre-rift and syn-rift sedimentary cover. On the other hand, in absence of décollement, our model predicts symmetric necking of the lithosphere devoid of any structure and related thermal regime geologically relevant to the Pyrenean case.

\section{Keywords}

North Pyrenean rifting - numerical modeling - décollement - syn-rift salt tectonics - mantle exhumation - high temperature metamorphism

\section{Introduction}

Rifting of the continental lithosphere fosters the development of rifts, passive margins and oceans. Rifting thus plays a central role in the plate tectonics framework. Moreover continental passive margins host sedimentary basins of particular economic interest (natural resources, storage). It is therefore essential to unravel the processes that govern lithospheric rifting.

Since three decades, analogue and numerical models have been widely used to investigate various aspects of rifting mechanics and deformation patterns that characterize rifted lithospheres (Dunbar and Sawyer, 1989; Benes and Davy, 1996; Brun and Beslier, 1996; Huismans and Beaumont, 2003; Liao and Gerya, 2014; Naliboff et al., 2017). Extensional patterns with specific tectonic implications have been explored in detail: 1) wide versus narrow rifts (Buck 1991; Brun, 1999; Gueydan et al., 2008; Tirel et al 2008), 2) oblique extension (Tron and Brun, 1991; McClay and White, 1995; Zwaan et al., 2016). The same occurred about thermal and magmatic aspects of rifting: 1) thermal regimes (Huet et al., 2011; Tirel et al., 2004), 2) melting (Bialas et al., 2010; Schmeling and Wallner, 2012; Davis and Lavier, 2017) or 3) hot versus cold margins (Corti et al., 2003). Of particular interest for the study of passive margins, are modeling works dedicated to: 1) the effects of stretching rate variations (Brun, 1999; Brune et al., 2016; Rey et al., 2009; Nestola et al., 2015; Tetreault and Buiter, 2018), 2) symmetry versus asymmetry of margins (Nagel and Buck, 2004 ; Huismans and Beaumont, 2007), 3) surface processes (Burov and Poliakov, 2001; Bialas and Buck, 2009) ,4) multiple phases of extension (Braun, 1992; Naliboff and Buiter, 
2015). Effects of small scale compositional inheritance on the development of passive margins has received limited attention, although such inheritance likely play an important role in the development of continental passive margins (Duretz et al., 2016; Jammes and Lavier, 2016).

Compositional pre-rift inheritance is of particular relevance for numerous margins in the present day Mediterranean as well as former peri-Tethyan basins. Their tectonic evolution was often influenced by the presence of thick Triassic deposits in the pre-rift stratigraphy, often characterized by evaporite sequences that are mechanically weak and often activated as efficient décollement horizons. Such pre-rift lithological heterogeneity is thus expected to act as a decoupling level between sedimentary cover and basement during passive margin formation. In such circumstances, the pre-rift cover undergoes extension above the décollement, giving birth to classical salt tectonics structures. This type of salt tectonics is driven by lithosphere extension and therefore is syn-rift. An outstanding example is the North Sea salt basin in which salt was deposited during the Permian whereas the maximum salt tectonics activity was Triassic-Jurassic (Nalpas and Brun, 1993; Stewart and Coward, 1995). Syn-rift salt tectonics strongly contrasts with salt tectonics observed at most South Atlantic margins (e.g. Fort et al., 2004; Mohriak, and Szatmari, 2001) where salt is deposited syn- to post-rift. Salt tectonics is in this case driven by gravity gliding downslope (Brun and Fort, 2011), the margin slope resulting from post-rift thermal subsidence.

In this study, we investigate the effects of a pre-rift décollement layer, located at sedimentary cover base, on the development of a continental rift. We emphasize the role of the décollement layer thickness on the style of salt tectonics and its impact on the structural, thermal and sedimentary evolution of the resulting conjugate passive margins. We characterize the first order features of margins that underwent syn-rift salt tectonics and compare our models to the geological data acquired in the Cretaceous Pyrenean Rift.

\section{The Cretaceous Pyrenean Rifting}

Amongst (peri-)Thetyan basins, one of the best-documented field examples exhibiting syn-rift salt tectonics is the Cretaceous Pyrenean Rift (CPR) that pre-dates the Cenozoic Pyrenean orogeny. Remnants of the rift zone are now exposed all along the northern flank of the belt, in the so-called North Pyrenean Zone (NPZ, Fig. 1a), in which the pre-rift sedimentary sequences are made, from Triassic to Cretaceous, of limestones, marls, 
marbles and dolomites. They are overlain by syn-rift flysch deposits, together with small bodies of exhumed sub-continental mantle and associated remnants of Variscan continental basement (Lagabrielle et al., 2010; Clerc and Lagabrielle, 2014; Corre et al., 2016). The Variscan basement is exposed in the prominent Axial Zone (AZ) that forms the highest reliefs of the Pyrenees. It consists in thrust and folded Cambrian to Carboniferous sediments and metasediments intruded by granitic plutons.

\section{Stratigraphy}

The upper Triassic marls and evaporites (Keuper deposits) are widespread across the Pyrenean belt (Fig. 1a). In the Bay of Biscay region, the Pyrenees and the Aquitanian Basin regions, the thickness of upper Triassic deposits ranges from 1000 to $2700 \mathrm{~m}$ (Biteau et al., 2006; Jammes et al., 2010b; Ortí et al., 2017; Roca et al., 2011; Saura et al., 2016). These deposits thus represent a major décollement level within the pre-rift stratigraphy (Biteau et al., 2006; James and Canérot, 1999; Jammes et al., 2010a) that controlled the development of Cretaceous syn-rift salt tectonics structures. Rollovers and tilted blocks are observed in basins located to the north and south of the present Pyrenees, like in Parentis and Aquitaine (Jammes et al., 2010b) or in Cotiella basins (McClay et al., 2004). Mesozoic platform carbonates (limestones, dolomites and marls) conformably overlay the Triassic deposits and form the original cover of the northern Iberian margin (Canerot et al., 1978; Canérot and Delavaux, 1986; Canérot, 1991). In the western Pyrenees - i.e. Chaînons Béarnais-, this prerift sequence reaches a thickness of $3000 \mathrm{~m}$ including Liassic, Middle and Upper Jurassic carbonates and Urgonian limestones (Canérot et al., 1978; Canérot and Delavaux, 1986; Canérot, 1991). Further north, in the Aquitaine basin the pre-rift sequence reaches a cumulated thickness of more than 4000 m (e.g. Biteau et al., 2006). Albian-Cenomanian flysch-type sediments were deposited during rifting (Souquet, 1985; Debroas, 1990). The total thickness of these syn-rift sediments exceeds 5000 m locally (Fig. 1b).

\section{Rifting}

Both the continental basement and pre-rift/syn-rift series have experienced low pressure / high temperature deformation during rifting (Golberg and Leyreloup, 1990). Peak temperatures recorded by the metamorphic sediments of the pre- and syn-rift cover range from $250^{\circ} \mathrm{C}$ to $600^{\circ} \mathrm{C}$ and are associated with the development of a syn-extensional tectonic 
foliation parallel to sedimentary bedding (SO/S1) (Clerc et al., 2015; Corre et al., 2016). The highest temperatures in the pre-rift sedimentary cover are located in regions of extreme crustal thinning and mantle exhumation, indicating that the pre-rift sediments were mechanically decoupled from the basement - i.e. décollement- by the Keuper clays (Clerc and Lagabrielle, 2014). The décollement promoted differential and asynchronous thinning of basement and cover correlated with large relative cover/basement motions (Fig. 1b). In this tectonic style, previously termed "lateral extraction" (e.g. Clerc and Lagabrielle, 2014), the pre- and syn-rift sedimentary formations remained located at rift center, in spite of large stretching, and in direct contact with the exhuming lithospheric mantle (Fig. 1c) (Jammes et al., 2010b; Lagabrielle et al., 2010). Such deformation patterns directly result from the interaction between crustal thinning and mantle ascent. They also explain the high temperatures recorded in the pre- and syn-rift sediments and the prevalence of ductile deformation in the continental basement and pre-rift sediments throughout rifting by a "blanketing" effect (thermal insulation of the basement by overlying sediments, Clerc et al., 2015). In addition, continuous flysch sedimentation in the deepening portions of the active rifts allows the preservation of high temperatures at basin axis during the final rifting stages.

Alternative interpretations of the CPR evolution have been proposed in previous studies (Jammes et al., 2010b; Masini et al., 2014; Tugend et al., 2014). In contrast with the observations and interpretations described above, these studies generally emphasize the role of structures arising from brittle deformation during rifting (e.g. so-called "extensional allochthons" in Jammes et al., 2010b and normal faults in Masini et al., 2014). While the role of pre-rift salt is described in Jammes et al., (2009b), Masini et al. (2014) consider that the middle crust is the dominant décollement horizon. In summary, these previous studies do not identify the fully allochthonous character of the pre-rift sedimentary cover and overlook the regional high temperature event, that is responsible for the late-stage ductile deformation including in the sedimentary cover.

In the present study, we employ two-dimensional thermo-mechanical modeling to study the role of a km-thick basement/cover décollement on the dynamics of lithospheric rifting and the mechanical interactions between the cover décollement and mantle ascent. Field data summarized above are used to calibrate the model parameters and, in turn, modeling results are applied to the CPR.

This article is protected by copyright. All rights reserved. 


\section{Numerical modeling}

The numerical thermo-mechanical models were designed based on a simple 2D initial setting inspired by the pre-rift stratigraphy of the CPR. In the reference model, the lithosphere consists in a three-layer crust made of a $25 \mathrm{~km}$ thick basement, a $1.5 \mathrm{~km}$ thick décollement horizon and a $3.5 \mathrm{~km}$ thick pre-rift cover. Both the décollement and pre-rift cover thicknesses represent conservative values according to estimates from the CPR region (see Sec. II). The crust is underlain by both mantle lithosphere (from $30 \mathrm{~km}$ to $100 \mathrm{~km}$ depth) and asthenosphere (from $100 \mathrm{~km}$ to $120 \mathrm{~km}$ depth) (Fig. 2). The model domain is a crosssection of $120 \times 300 \mathrm{~km}$ and the numerical resolution is $150 \mathrm{~m}$ in both dimensions. A constant normal velocity is applied at the boundaries of the model $\left(2\left|V_{\text {out }}\right|=1 \mathrm{~cm} / \mathrm{y}\right)$. The model top boundary is a true free surface (Duretz et al., 2016) along which erosion and sedimentation are parameterized. In order to satisfy mass conservation, an inflow velocity $\left(V_{\text {in }}\right)$ is imposed at the base of the model. An initial temperature anomaly $(+50 \mathrm{~K}, 5 \mathrm{~km}$ radius) located in the mantle lithosphere (Fig. 2) allows seeding the deformation. The initial geotherm is computed assuming steady state and accounts for different radiogenic heat production in each layer (Table 1$)$ and a constant asthenosphere temperature $\left(1350^{\circ} \mathrm{C}\right)$. In the reference model, we consider a major source of inheritance represented by the $1.5 \mathrm{~km}$ thick décollement layer of salt rheology located at the interface between cover and basement. This décollement thus represents the Upper Triassic marls and evaporite sequence (Keuper). The presented models do not account for any pre-defined strain softening parameterization. For details regarding the overall methodology (mathematical model and algorithms), see the Appendix.

First, we describe the evolution of our reference model, that is characterized by an initial Moho temperature of $480^{\circ} \mathrm{C}$, a homogeneous basement (i.e. single layer), a total extension velocity of $1 \mathrm{~cm} / \mathrm{y}$ and a $1.5 \mathrm{~km}$ thick décollement layer. Second, we highlight the key role played by the thickness of the décollement layer. Last, we describe models that accounted for different initial Moho temperature, basement structure and extension rates.

This article is protected by copyright. All rights reserved. 


\section{III.1 The reference model}

\section{Initiation of extension}

The earliest stages of extension lead to the development of a heterogeneous style of thinning (Fig. 3a). In the pre-rift cover, strain strongly localizes while basement thinning and necking of the lithosphere mantle are more distributed. Localized cover thinning, primarily in the frictional regime, is located above both rift shoulders at $\sim 70 \mathrm{~km}$ away from rift center (Fig. 4b). A central cover boudin is disconnected from the lateral sides and preserved from any further deformation (Fig. 4a,b). Basement thinning that is most pronounced in regions adjacent to the rift center (e.g. $x=+35 \mathrm{~km}$ ) and involves equivalent amount of frictional and ductile deformation (Fig. 4a,b). The Moho geometry is characterized by sharp and high amplitude variations (>5 km, Fig. 3a) that are caused by frictional deformation that takes place at the onset of extension (not depicted).

\section{Smooth slope basin}

With ongoing extension (Figs. 3b, 4c,d), the cover is locally dissected and folded leading to a sequence of second-order syn-kinematic rollover structures separated by rafts ("turtle backs") that are better expressed above rift shoulders. Above rift axis, the pre-rift cover forms a large-scale syncline in which a syn-kinematic basin is deposited (Fig. 3b). Note that this type of basin, characterized by smooth slopes, smooth bedding curvature and absence of bounding faults, is commonly called "sag basin" in passive margin literature. This could be misleading because it is in fact a syn-rift basin located on top of a stretched crust. Basement thinning becomes visible in the regions located at rift center $(x=-30 \mathrm{~km}$ and $\mathrm{x}=$ $+40 \mathrm{~km}$ ). Basement deformation still involves both ductile (Fig. 4c) and frictional rheological components (Fig. 4d). Basement faults are well expressed. The necking of lithosphere mantle that is accommodated by ductile deformation is almost complete (Fig. 4c).

\section{Basement thinning}

After $10 \mathrm{My}$ (Fig. 3c, 4e,f), the lithosphere is fully necked, the basement is thinned down to a thickness of less than $5 \mathrm{~km}$ while the pre-rift cover is not yet thinned (Fig 3e). The discrepancy between the rates of thinning in basement and cover thinning represents a striking feature of the model. Basement thinning mainly occurs between the $400^{\circ} \mathrm{C}$ and $600^{\circ} \mathrm{C}$ isotherms. Ongoing deformation is thus dominated by pervasive ductile deformation (Fig 4e). Deformation of pre- and syn-rift cover localizes along faults, $40 \mathrm{~km}$ away from rift 
center (Fig. 3c). Asthenosphere rises up, beneath the non-thinned pre-rift cover, in response to continued extension. The thickness of syn-rift deposits reaches $3 \mathrm{~km}$ in the central "sag" basin and $5 \mathrm{~km}$ in the adjacent rollover structures.

\section{Mantle exhumation}

During the latest stages of rifting (Fig. $3 \mathrm{~d}, 4 \mathrm{~g}, \mathrm{~h}$ ), the basement layer thickness is locally reduced to zero. Thus, the allochthonous pre-rift cover directly lies on the exhuming mantle (Fig. 3d). The pre-rift cover also thins down, leading to the development of a rollover structure located on top of the exhuming mantle. As a result, the temperature within the pre- and syn-rift cover and the décollement can locally rise above $400^{\circ} \mathrm{C}$ by conductive heating. Consequently, the pre-rift cover becomes affected by ductile deformation (Fig. 4g). Note that the basement appears disrupted due to extreme stretching (Fig. 5a). In fact, this thinning is passive and does not result from a necking instability but from the deformation of the underlying mantle. When reaching shallower levels $(<10 \mathrm{~km})$ and cooling down the mantle becomes brittle (Fig. 4h) and undergoes faulting. Relative displacements between fault blocks passively deform the overlying ductile crust, mimicking a strong layer necking. This process initiates as soon as the top of the exhuming mantle becomes brittle (here at 11-12 My). Diapirs develop from the décollement layer in the necking zones of the pre-rift cover (e.g. $x=-50 \mathrm{~km}$ ). Tight associations of exhumed mantle, pre- and syn-rift sediments and lenses of extremely stretched basement occur where the pre-rift cover thins down $(x=$ $30 \mathrm{~km}$, Fig. 5a). The décollement layer accommodates most of the strain (Fig. 5b). While deformation in the sedimentary cover is localized, mantle deformation is rather distributed (Fig. 5b). The basement exhibits a transitional deformation style made of anastomosed shear bands ( $x=55 \mathrm{~km}$, Fig, $5 \mathrm{~b}$ ).

\section{III.2 The effect of décollement thickness on rift evolution}

In absence of a décollement layer the rift structure is strikingly symmetric (Fig. 6a). The overall structure consists of a single symmetric lithospheric necking zone with thin syn-rift deposits at rift center and two lateral syn-rift depocenters ( $\sim 5 \mathrm{~km}$ thick) located on proximal margins, adjacent to rift shoulders. The pre-rift cover remains welded to basement and move away from rift axis as basement is laterally disrupted. The pre-rift cover is thus never exposed to high temperatures related to ascent and exhumation of the mantle.

This article is protected by copyright. All rights reserved. 
A thin décollement layer $(750 \mathrm{~m})$ is sufficient to promote mechanical decoupling between cover and basement (Fig. 6b). It thus leads to a notably different style of extension than without a décollement (Fig. 6a). The cover accommodates extension by localized deformation that triggers the formation of numerous small-scale basins. It first necks away from rift center, in the rift shoulder regions, and then extension remains located at rift center until the basement is laterally disrupted. Cover extension, in rift shoulders regions, is accommodated by distributed localized deformation giving numerous small-scale basins with structure of rollover or turtle-back structures (Fig. 6b). Finally, the cover also undergoes necking at rift center, where it is segmented and separated blocks are incorporated to the distal parts of both margins.

Thicker décollements (1.5 and $3 \mathrm{~km}$ ) further enhance decoupling between basement and cover. In rift shoulder regions, the cover rapidly necks giving either rollover-type structures (Fig. 3c) or diapirs fed by the underlying décollement that can even be exhumed and exposed to the surface (Fig. 3d). The pre-rift cover remains located at rift center during the entire extension and becomes thus exposed to heating by conduction above the exhuming mantle. Most of the small-scale basins are bounded by diapirs rising from the décollement horizon (Fig $6 \mathrm{~d}$ ). Models including thick décollements (Fig $6 \mathrm{c}$,d) develop long hyper-thinned basement lenses ( $50 \mathrm{~km}$ width). These are consequences of the high temperature reached by the basement, which enhances its ability to flow viscously

In summary, in absence of décollement, the pre-rift cover remains welded to the basement. After a finite amount of stretching, the pre-rift cover is absent in most of the rift basin. Only syn-rift sediments are present in the distal part of margins, directly deposited on top of the almost exhumed mantle. The presence of a décollement promotes basementcover decoupling. At a given rate of extension (here $1 \mathrm{~cm} / \mathrm{y}$ ) and for a décollement of moderate thickness (here up to $1.5 \mathrm{~km}$ ), pre-rift cover necking gives birth to rafts from the shoulder regions to the distal part of margins. Syn-rift sediments accommodate the growth of rollover basins between the rafts. An increase of décollement thickness (here up to $3 \mathrm{~km}$ ) promotes the development of large salt diapirs and wider rafts. Finally, the asymmetry of the pre-rift cover deformation and the asymmetry of the overall rift structure increase with the décollement thickness.

This article is protected by copyright. All rights reserved. 


\section{III.3 Influence of lithospheric rheology, initial and boundary conditions.}

In order to test the robustness of model features described above, we examined the effects of different initial, boundary conditions and rheological properties (Fig. 7). The thickness of salt décollement is set to $1.5 \mathrm{~km}$ as in the reference model (Fig. 3, Fig. 6c).

First, we tested different mantle rheological model and crustal rheological structure. On one hand we deactivated Peierls creep of olivine (Fig. 7a), thereby allowing larger stress to develop in the mantle. On the other hand, we accounted for a two-layer crust incorporating a strong lower crust (Fig. 7b). The model that neglects Peierls creep (Fig. 7a) most resembles the reference model. It produces a very similar style of basement and mantle deformation. The model that includes a layered crust has a less pronounced Moho topography and relatively less thinned crust (Fig. 7b). The resulting central basin contains a thinner syn-rift infill. The syn-rift sediments reach moderately high temperatures close to the rift center $\left(<400^{\circ} \mathrm{C}\right)$. We did not modify salt rheology in the décollement. Since salt is much weaker than any other typical crustal material (Weijermars et al., 1993), saltdominated horizons are expected to always act as efficient décollements.

Second, we investigated the effects of the initial thermal condition. Two different initial Moho temperatures $\left(530^{\circ} \mathrm{C}\right.$ and $560^{\circ} \mathrm{C}$ ) were considered. The resulting models show only minor differences with regard to the reference model (Fig. 7c,d). The base of the prerift cover may reach up to $650^{\circ} \mathrm{C}$ for an initial Moho temperature of $560^{\circ} \mathrm{C}$ (Fig. $7 \mathrm{~d}$ ). In comparison with the reference run, models with higher Moho temperatures are characterized by slightly more symmetric basement deformation style.

Last, we tested the influence of various extension rates. The resulting models exhibit more visible differences with regard to the reference model. Fast extension rates promote the formation of narrower cover rafts, (Fig. e and f) and also foster the development of numerous normal faults within the thinned basement. In addition, slower extension rates induce slightly more asymmetric basement deformation and wider and thicker rollover basins.

At first-order, all above-described models share the same style of syn-rift salt tectonics. The pre-rift cover evolves into rafts and large portions of the pre-rift cover are present in the rift basin. The syn-rift sediments are mostly involved into rollover basins. The overall basement and mantle lithosphere deformation is symmetric. In summary, the

This article is protected by copyright. All rights reserved. 
presented models share first order similarities with the reference mode and are controlled by the activation of the pre-rift décollement layer.

\section{III.4 Thermal regime}

The thermal evolution of pre-rift and syn-rift sediments with and without a pre-rift salt décollement is depicted in Figure 8. Models without a décollement do not exhibit any type of basement/cover mechanical decoupling and, consequently, the cover never comes in contact with the exhuming mantle and maximum temperatures reached in both pre- and syn-rift sediments remain lower than $300^{\circ} \mathrm{C}$ (Fig. 8c). Conversely, when a décollement is present, the allochthonous cover remains located at rift axis and undergoes a regional heating. Pre-rift sediment temperatures increase by about $250-300^{\circ} \mathrm{C}$ in most of the basin (Fig. 8). The maximum temperature recorded by the pre-rift sediments can locally exceed $500^{\circ} \mathrm{C}$ and the syn-rift sediments can reach temperatures up to $400^{\circ} \mathrm{C}$. The pre-rift cover that remains located above the thermal anomaly related to mantle ascent, induces a thermal blanketing effect. Largest pre- and syn-rift temperatures are recorded in the vicinity of the exhumed mantle (Fig. 8a) and more specifically in rollover structures made of the synrift sediments (Fig. 8b). During exhumation, mantle undergoes a cooling of about $600^{\circ} \mathrm{C}$. Consequently, the overlying sedimentary cover is subjected to a heating of about $500^{\circ} \mathrm{C}$ locally (Fig. 8c). In the reference model, cover heating occurs after $12 \mathrm{Ma}$, what coincides with the timing of mantle exhumation. This clearly illustrates the control of the pre-rift salt décollement on the thermal evolution of pre- and syn-rift sequences. The above numbers may vary with the initial Moho temperature. We observed that the pre-rift cover temperature locally rises up to $650^{\circ} \mathrm{C}$ for initially elevated geotherms (e.g. $560^{\circ} \mathrm{C}$ Moho temperature, Fig. 7d).

\section{Discussion}

\section{IV.1 The first order role of the décollement}

Our models highlight the first order role played by the décollement at pre-rift cover base. In absence of a décollement, the pre-rift cover remains coupled to the underlying basement. The cover is thus taken away from rift center during crustal necking such that no 
pre-rift cover remains in the main rift basin after basement thinning and mantle exhumation (Fig. 6a to d).

The presence of a décollement layer leads to an efficient basement-cover decoupling. The cover can deform and neck independently from the basement and can remain in the main rift basin as the underlying basement is extracted from rift center (Figs. $3 c$ and d). After basement thinning, the exhuming mantle underlies the cover. As a result, the sedimentary cover undergoes high temperatures $\left(T>500^{\circ} \mathrm{C}\right)$, in accordance with the high temperature event recorded during the formation of the Pyrenean rifted margins (Vacherat et al., 2014, Clerc et al., 2015).

In the reference model, the salt décollement strongly controls the style of thinning in the sedimentary cover (Fig. 9a). Deformation and development of structures are characteristic of a syn-rift salt tectonics driven by crustal extension, as in the North Sea (Nalpas and Brun, 1993; Stewart and Coward, 1995) while post-rift salt tectonics, as commonly observed along Atlantic passive margins, mainly involves downslope gravity gliding (Brun and Fort, 2011).

Extreme cover thinning occurs above rift shoulders (Fig. 3a) leading to the formation of faulted blocks (i.e. horsts and graben or tilted blocks) and rollover structures with synkinematic growth (Fig. 9a). Normal faults dipping toward rift axis that control the formation of tilted blocks, indicate a sense of shear top-to-rift axis in the décollement layer (Fig. 9a). This extensional pattern then amplifies with increasing extension. Latest stages of extension exhibit segmentation of the initial pre-rift cover in rafts whose spacing increases with stretching. Large rollovers take place along rift shoulders in relation with the top-to-rift axis shear (Fig. 3f).

In terms of relative displacements, a central raft remains located at rift axis during the whole extension history (Fig. 3a to d). Most of cover thinning occurs along the smooth slopes that develop in the former rift shoulder region (Fig. 3a, Fig. 5a). In the rift limbs, large basement/cover relative displacements take place with a top-to-rift axis sense of shear (Fig. 9b). This displacement pattern is the result of the combination of two factors. The first is purely kinematic: the cover is locally necked and laterally disrupted while the underlying basement is continuous and subjected to regional extension (i.e. due to boundary condition). The second is active, as a result of downslope gravity instability of the sedimentary cover. Gliding of the whole sedimentary cover toward rift axis -i.e. downslope 
rift limbs- is favored by the weak viscous strength of the basal salt layer (décollement). The sedimentary cover, on top of the salt décollement, undergoes a combination of layerparallel stretching and layer-parallel shear, top-to-rift axis that control normal faulting, rafting and, at increasing amounts of stretching, rollovers and salt diapirs. Within the main central "sag" basin located at rift axis, this syn-rift kinematic pattern may locally cause a slight contraction. This results from the convergence of two gravity glides of the pre-rift cover with opposite senses. At large scale, this is illustrated by the kinematic pattern observed in models (e.g. Fig. 9) in which the pre-rift cover moves toward rift center whereas the underlying basement is moving opposite. This apparent paradox, a rather surficial zone of contraction located in the middle of an extending rift, is a direct consequence of the presence of a salt décollement at sedimentary cover base

Finally, the syn-rift salt tectonics style described here appears rather independent of reasonable variations of the classical parameters that can control lithosphere rifting (i.e., applied extension rates, initial thermal structure, and mantle rheology). In either case shown in Figure 7, the décollement allows for the activation of syn-rift salt tectonics and thus plays a major role in shaping the architecture of the continental margins.

\section{IV.2 Comparison between the model and the Cretaceous Pyrenean rift}

At first order and at the largest scale, the final stages of the model display five types of structural domains that can be compared to structures observed in the Cretaceous Pyrenean rift (Fig. 10b1). The less deformed ones correspond to the proximal margin domains that preserve original crustal thickness. At rift center, extremely thinned crustal units rest on top of an exhumed mantle domain (Fig. 10b3). This region may correspond to a distal margin domain where mantle rocks are exhumed between disconnected crustal lenses. Natural examples of such rock association may be found in the NPZ region (e.g. Saraillé, Urdach, Lherz) where Iherzolites bodies are currently outcropping (Fig. 10b3) (Lagabrielle et al., 2010; Corre et al., 2016; Asti et al., 2019). Between the proximal and distal domains, large normal faults define tilted blocks in the basement (Fig. 10b4) that can be compared to the North Pyrenean massifs (e.g. Trois Seigneurs, Arize, Saint Barthélemy, Agly) (Vacherat et al., 2016). Associated sedimentary depocenters are located partly on top of tilted blocks and partly above the main normal faults. This domain may correspond to the

This article is protected by copyright. All rights reserved. 
most external portions of the NPZ and internal foreland of the Northern Pyrenees. It includes the basins that formed close to the proximal margin, such as the Camarade, Nalzen or Massat basins. Finally, in the proximal basins, diapirs of Triassic evaporites pierce the prerift cover and may control the evolution of two different types of sub-basins (Clerc et al., 2016) (Fig. 10b5). Outside the NPZ, on the southern flank of the Mouthoumet massif and northern flank of the Agly and Salvezines massifs, localized thinning and basal truncation of pre-rift cover blocks (Fig. 10b1) result from gliding toward the Saint Paul de Fenouillet and Bas-Agly (Clerc et al., 2016). The model also displays in the proximal domain syn-rift sedimentary basins dominated by rollover structures above the décollement. Such structures are reported at various other places in the Pyrenees, like Cotiella (McClay et al., 2004) (Fig. 10b2).

At a second order, the transition between proximal and distal domains displays a striking feature. The preserved pre-rift cover is located inside the extending system and is direct contact with the exhumed mantle (Lagabrielle et al., 2010) (Fig. 10b3). The presence of a basement-cover décollement enhances the horizontal motion component in crustal extension. This leads to the tectonic superposition of deformed pre-rift sediments and mantle units (Clerc and Lagabrielle, 2014). As stated earlier, the geological record clearly indicates that the Pyrenean pre-rift Mesozoic cover was efficiently decoupled from the Variscan basement, thanks to Late Triassic (Keuper) evaporites and clays layers (Jammes et al., 2010b; Lagabrielle et al., 2010).

At a third order, the thermal evolution during progressive mantle ascent is consistent with the evolution deduced from paleo-temperatures measured in the NPZ that have been recently completed (Clerc et al., 2015). Close to mantle bodies, temperatures are up to $600^{\circ} \mathrm{C}$ in the pre-rift whereas most of the syn-rift black flysch (so-called "flysch noir") displays rather homogeneous temperatures, around $350^{\circ} \mathrm{C}$ in the Chaînons Béarnais. This suggests a slow and continuous heating rather than fast and localized thermal pulses. On the distal margin, high geothermal gradient, in relation with crustal extension associated to mantle exhumation, is supported by the range of AFT and ZHe ages from the northern Pyrenees (Mouthereau et al., 2014; Vacherat et al., 2014; Hart et al., 2017) and is consistent with reconstructions of the paleo-geothermal gradient during the Pyrenean Cretaceous rifting (Espurt et al., 2019). In general, peak temperatures recorded in the western NPZ are lower than those recorded in the eastern part (e.g. up to $\sim 600^{\circ} \mathrm{C}$ in the Aulus and 
Boucheville basins). Considering that the temperature increases significantly once the mantle is exhumed up to the sedimentary cover base (Fig. 8), differences might be due to variations in the style and amount of crustal thinning along the Cretaceous rift system. For example, exposed mantle bodies are attached to thin crustal lenses in the western NPZ (Asti et al., 2019), but not in the eastern NPZ (Lagabrielle et al., 2010). Another noticeable alongstrike difference concerns the sedimentary reworking of exhumed mantle, rare in western NPZ (only around Urdach massif) and more common and synchronous with exhumation in eastern NPZ (Lagabrielle and Bodinier, 2008; Lagabrielle et al., 2010; de Saint Blanquat et al., 2016).

In the numerical model, high temperatures trigger ductile deformation in a large portion of the pre-rift cover that remains located at basin center. This is also in agreement with field evidence for ductile deformation (Saraillé, Urdach-Les Pernes and Turon de la Técouère) in the pre-rift sediments (Lagabrielle et al., 2010; Corre et al., 2016) that have been confirmed by Electron Back-Scattered Diffraction (EBSD) analysis of the intracrystalline deformation of the North Pyrenean marbles (Vauchez et al., 2013; Lagabrielle et al., 2016).

The model reproduces some characteristics of previous models of the CPR (Jammes et al., 2010b; Masini et al., 2014; Tugend et al., 2014). Normal faults (Masini et al., 2014) indeed developed in the basement but only in the initial stages of extension, prior to high temperature events (Fig. 4d). In the model, faults that are either located in the pre-rift cover or in the basement do not cut across the décollement layer. The contribution of basement faults to rifting at large scale is limited as strain is mostly accommodated by structures linked to the salt décollement (Fig. 5b).

Some model structures resemble to the so-called "extensional allochthons" sometimes described in passive margins and interpreted as a product of low angle detachment faulting. However, these structures result from the extension undergone by the pre-rift sedimentary cover (Figs. 5 and 9a) during gliding above the salt décollement. They correspond to structures of raft type (Mauduit et al., 1997b) or "turtle back" type (Mauduit et al., 1997a) types rather common in salt tectonics (Duval et al., 1992; Fort et al., 2004). They do not result from low angle detachment faulting. Thus, the overall deformation style shares some geometric similarities rather than kinematic with the model of "Salt pre-rift with décollement in the salt layer" described in Jammes et al. (2010b).

This article is protected by copyright. All rights reserved. 
Our model does not account for the exhumation of the lower crust along detachment faults during the latest stages of the CPR. While this mechanism has been previously emphasized (Labourd area; Jammes et al., 2009; Masini et al., 2014), recent work has challenged this view (Saspiturry et al., 2019). Indeed, exhumation of granulites originating from the lower crust has occurred in the Pyrenees during Hercynian extension (e.g. Bouhallier et al., 1991; Vissers et al., 1992; Saint Blanquat, 1993), therefore predating the formation of the CPR (Saspiturry et al., 2019).

\section{IV.3 Model limitations}

In the presented model, the mantle exhumed to basin floor originates from depth larger than $100 \mathrm{~km}$. However, petrologic data suggest that the mantle exhumed in the North Pyrenean realm originates from shallow depths (i.e. sub-continental mantle) as it did not experience melting nor re-fertilization during its exhumation (Picazo et al., 2016). In fact, the latest re-fertilization event experienced by the sub-continental mantle exposed in the Lherz massif is likely related to late-Variscan events (Le Roux et al., 2007).

There are also general limitations concerning kinematic aspects of the model. While the modeling was carried out in 2D, the NPZ is non-cylindrical and incorporates important lateral variations. This implies that the role of transtensional deformation cannot be inferred from the presented models. Indeed, the Europa/Iberia relative motion implies a certain amount of left-lateral motion (Olivet, 1996; Sibuet et al., 2004; Gong et al., 2008). The opening style of the north Pyrenean mid-Cretaceous basins is also debated. Basins might have opened as a series of pull-apart basins (Choukroune and Mattauer, 1978; Canérot, 1988; Debroas, 1988) or due to oblique rifting (Jammes et al., 2010b; Masini et al., 2014; Tugend et al., 2014). In the presented models, symmetrical sedimentary basins develop on both sides of the distal domain. Regardless of whether pull-apart basins or oblique rifting dominated, basin opening along the NPZ axis likely developed in a noncylindrical way. Therefore, the proposed cross-sections (Fig. 1c) cannot be repeated cylindrically all along the Pyrenees during the Late Cretaceous. The same applies to the regions where mantle rocks were exhumed and further exposed at the seafloor. Mantle exhumation did not occur in a single continuous trough, but rather in separate basins.

This article is protected by copyright. All rights reserved. 
In order to focus the role of the pre-rift salt décollement, we have neglected the role of potential basement heterogeneities. For this reason, all the presented models are characterized by a roughly symmetric extension of basement and mantle lithosphere. Notable asymmetries can be observed above the basement top, in the models including a décollement. These asymmetries affect the structure of the décollement structure and the pre-rift and syn-rift sediments.

The thermal effect of fluid circulations is not included in the presented models. However porous convection may have occurred in the developing basins, which would notably modify the overall thermal regime (e.g. Souche et al., 2014).

\section{Conclusions}

Based on geological observations of the Cretaceous Pyrenean Rift, we have designed a thermo-mechanical model of lithosphere rifting. We have systematically tested the influence a km-scale pre-rift décollement on the thinning of lithospheres. Despite the overall simplicity of the employed rheological model and applied boundary conditions, the numerical model captures key features of the CPR. The pre-rift evaporitic layer acted as a cover-basement décollement allowing for the development of structures that are typical of syn-rift salt tectonics (rafts, rollovers, diapirs, smooth slope basins) as described in the CPR. As a consequence, pre-rift sediments were decoupled from the basement and came locally in direct contact with the exhuming mantle. Conductive heating hence induces high temperature $\left(T>500^{\circ} \mathrm{C}\right)$ within the pre-rift sediments, in agreement with geological data of the CPR. More generally, our experiments demonstrate that the presence of a pre-rift salt décollement at the base of a thick pre-rift sedimentary cover exerts a first order control on rift evolution and passive margin architecture.

\section{Acknowledgements}

The authors thank John Naliboff and an anonymous reviewer for their constructive comments. We also acknowledge the editor Cynthia Ebinger for handling the manuscript. RA wish to thank the OROGEN Project (BRGM, Total, CNRS-INSU) for providing a post-doc grant.

\section{Data Availability Statement}

The data that support the findings of this study are available from the corresponding author upon reasonable request. 


\section{References}

Asti, R., Lagabrielle, Y., Fourcade, S., Corre, B., Monié, P., 2019. How do continents deform during mantle exhumation? Insights from the northern Iberia inverted paleopassive margin, western Pyrenees (France). Tectonics 38, 1666-1693.

https://doi.org/10.1029/2018TC005428

Benes, V., Davy, P., 1996. Modes of continental lithospheric extension: experimental verification of strain localization processes. Tectonophysics 254, 69-87. https://doi.org/10.1016/0040-1951(95)00076-3

Bialas, R.W., Buck, W.R., 2009. How sediment promotes narrow rifting: Application to the Gulf of California. Tectonics 28. https://doi.org/10.1029/2008TC002394

Bialas, R.W., Buck, W.R., Qin, R., 2010. How much magma is required to rift a continent? Earth Planet. Sci. Lett. 292, 68-78. https://doi.org/10.1016/j.epsl.2010.01.021

Biteau, J.-J., Marrec, A.L., Vot, M.L., Masset, J.-M., 2006. The Aquitaine Basin. Pet. Geosci. 12, 247-273. https://doi.org/10.1144/1354-079305-674

Bouhallier, H., Choukroune, P., Ballèvre, M., 1991. Evolution structurale de la croute profonde hercynienne; exemple du massif de l'Agly (Pyrénées orientales, France). C. R. Acad. Sci. Paris Ser. II 312, 647-654.

Braun, J., 1992. Postextensional mantle healing and episodic extension in the Canning Basin. J. Geophys. Res. Solid Earth 97, 8927-8936. https://doi.org/10.1029/92JB00584

Brun J.-P., 1999. Narrow rifts versus wide rifts: inferences for the mechanics of rifting from laboratory experiments. Phil. Trans. Roy. Soc., London, A, 357, 695-710.

Brun, J.-P., Beslier, M.-O., 1996. Mantle exhumation at passive margins. Earth Planet. Sci. Lett. 142, 161-173. https://doi.org/10.1016/0012-821X(96)00080-5

Brun, J.-P., Fort, X., 2011. Salt tectonics at passive margins: Geology versus models. Mar. Pet. Geol. 28, 1123-1145. https://doi.org/10.1016/j.marpetgeo.2011.03.004

Brune, S., Williams, S.E., Butterworth, N.P., Müller, R.D., 2016. Abrupt plate accelerations shape rifted continental margins. Nature 536, 201-204.

Burov, E., Poliakov, A., 2001. Erosion and rheology controls on synrift and postrift evolution: Verifying old and new ideas using a fully coupled numerical model. J. Geophys. Res. Solid Earth 106, 16461-16481. https://doi.org/10.1029/2001JB000433

Canérot, 1988. Manifestations de l'halocinèse dans les Chaînons Béarnais (Zone NordPyrénéenne) au Crétacé inférieur. Comptes Rendus L’Académie Sci. Paris 306, 10991102.

Canérot, J., 1991. Comparative study of the Eastern Iberides (spain) and the Western Pyrenees (France) Mesozoic basins. Palaeogeogr. Palaeoclimatol. Palaeoecol., Palaeogeography and Paleoceanography of Tethys 87, 1-28. https://doi.org/10.1016/0031-0182(91)90128-E

Canérot, J., Delavaux, F., 1986. Tectonics and sedimentation on the north- Iberian 
margin, 'chainons bearnais' south-Pyrenean zone (Pyrenees basco-bearnaises) . New data about the significance of the lherzolites in the Saraille area. Comptes Rendus Acad. Sci., II 302, 951-956.

Canerot, J., Peybernes, B., Ciszak, R., 1978. Presence d'une marge meridionale a l'emplacement de la zone des chainons bearnais (Pyrenees basco-bearnaises). Bull. Société Géologique Fr. S7-XX, 673-676. https://doi.org/10.2113/gssgfbull.S7-XX.5.673

Carter, N.L., Horseman, S.T., Russell, J.E., Handin, J., 1993. Rheology of rocksalt. J. Struct. Geol. 15, 1257-1271. https://doi.org/10.1016/0191-8141(93)90168-A

Choukroune, P., Mattauer, M., 1978. Tectonique des plaques et Pyrénées: sur le fonctionnement de la faille transformante nord-pyrénéenne; comparaison avec des modèles actuels. Bull. Soc. Geol. Fr. XX, 689-700.

Clerc, C., Lagabrielle, Y., 2014. Thermal control on the modes of crustal thinning leading to mantle exhumation: Insights from the Cretaceous Pyrenean hot paleomargins. Tectonics 33, 1340-1359. https://doi.org/10.1002/2013TC003471

Clerc, C., Lagabrielle, Y., Labaume, P., Ringenbach, J.-C., Vauchez, A., Nalpas, T., Bousquet, R., Ballard, J.-F., Lahfid, A., Fourcade, S., 2016. Basement - Cover decoupling and progressive exhumation of metamorphic sediments at hot rifted margin. Insights from the Northeastern Pyrenean analog. Tectonophysics 686, 82-97. https://doi.org/10.1016/j.tecto.2016.07.022

Clerc, C., Lahfid, A., Monié, P., Lagabrielle, Y., Chopin, C., Poujol, M., Boulvais, P., Ringenbach, J.-C., Masini, E., de St Blanquat, M., 2015. High-temperature metamorphism during extreme thinning of the continental crust: a reappraisal of the North Pyrenean passive paleomargin. Solid Earth 6, 643-668. https://doi.org/10.5194/se-6-643-2015

Corre, B., Lagabrielle, Y., Labaume, P., Fourcade, S., Clerc, C., Ballèvre, M., 2016. Deformation associated with mantle exhumation in a distal, hot passive margin environment: New constraints from the Saraillé Massif (Chaînons Béarnais, NorthPyrenean Zone). Comptes Rendus Geosci., From rifting to mountain building: the Pyrenean Belt 348, 279-289. https://doi.org/10.1016/j.crte.2015.11.007

Corti, G., Wijk, J.V., Bonini, M., Sokoutis, D., Cloetingh, S., Innocenti, F., Manetti, P., 2003. Transition from continental break-up to punctiform seafloor spreading: How fast, symmetric and magmatic. Geophys. Res. Lett. 30.

https://doi.org/10.1029/2003GL017374

Crameri, F., 2018. Geodynamic diagnostics, scientific visualisation and StagLab 3.0. Geosci. Model Dev. 11, 2541-2562. https://doi.org/10.5194/gmd-11-2541-2018

Davis, J.K., Lavier, L.L., 2017. Influences on the development of volcanic and magma-poor morphologies during passive continenta rifting: Geosphere, 13, 15241540. https://doi.org/10.1130 /GES01538.1.

de Saint Blanquat, M., Bajolet, F., Grand'Homme, A., Proietti, A., Zanti, M., Boutin, A., Clerc, C., Lagabrielle, Y., Labaume, P., 2016. Cretaceous mantle exhumation in the central Pyrenees: New constraints from the peridotites in eastern Ariège (North Pyrenean zone, France). Comptes Rendus Geosci., From rifting to mountain building: the Pyrenean Belt

This article is protected by copyright. All rights reserved. 
348, 268-278. https://doi.org/10.1016/j.crte.2015.12.003

Debroas, 1988. Le flysch noir albo-cénomanien témoin de la structuration albienne à sénonienne de la Zone nord-pyrénéenne en Bigorre (Hautes-Pyrénées, France). Bull Soc Géol Fr., 8 5, 273-286.

Debroas, E.J., 1990. Le flysch noir albo-cenomanien temoin de la structuration albienne a senonienne de la Zone nord-pyreneenne en Bigorre (Hautes-Pyrenees, France). Bull. Société Géologique Fr. VI, 273-285. https://doi.org/10.2113/gssgfbull.VI.2.273

Dunbar, J.A., Sawyer, D.S., 1989. How preexisting weaknesses control the style of continental breakup, J. Geophys. Res. Solid Earth, 94,B6,7278-7292 https://doi.org/10.1029/JB094iB06p07278

Duretz, T., Petri, B., Mohn, G., Schmalholz, S.M., Schenker, F.L., Müntener, O., 2016. The importance of structural softening for the evolution and architecture of passive margins. Sci. Rep. 6, 38704. https://doi.org/10.1038/srep38704

Duretz, T., May, D.A., Yamato, P., 2016. A free surface capturing discretization for the staggered grid finite difference scheme. Geophys J Int 204, 1518-1530.

https://doi.org/10.1093/gji/ggv526

Duval, B., C. Cramez, M. P. A. Jackson, 1992. Raft tectonics in the Kwanza Basin, Angola: Mar Petrol Geol 9, 389- 404.

Espurt, N., Angrand, P., Teixell, A., Lapaume, P., Ford, M., de Saint Blanquat, M., Chevrot, S., 2019. Crustal-scale balanced cross-section and restorations of the Central Pyrenean belt (Nestes-Cinca transect): Highlighting the structural control of Variscan belt and Permian-Mesozoic rift systems on mountain building. Tectonophysics 764, 2545. https://doi.org/10.1016/j.tecto.2019.04.026

Fort X. Brun J-P and Chauvel F., 2004. Salt tectonics on the Angolan margin, synsedimentary deformation processes. Bull Am Ass Petrol Geol, 88, 1523-1544.

Golberg, J.M., Leyreloup, A.F., 1990. High temperature-low pressure Cretaceous metamorphism related to crustal thinning (Eastern North Pyrenean Zone, France). Contrib. Mineral. Petrol. 104, 194-207. https://doi.org/10.1007/BF00306443

Gong, Z., Dekkers, M.J., Dinarès-Turell, J., Mullender, T. a. T., 2008. Remagnetization mechanism of Lower Cretaceous rocks from the Organyà Basin (Pyrenees, Spain). Stud. Geophys. Geod. 52, 187-210. https://doi.org/10.1007/s11200-008-0013-3

Gueydan F., Morency C., Brun J.-P. 2008. Continental rifting as a function of lithosphere mantle strength, Tectonophysics, 460, 83-93, https://doi.org/10.1016/j.tecto.2008.08.012

Hansen, F.D., Carter, N.L., 1983. Semibrittle Creep Of Dry And Wet Westerly Granite At 1000 MPa, in: ARMA-83-0429. Presented at the The 24th U.S. Symposium on Rock Mechanics (USRMS), American Rock Mechanics Association, ARMA, p. 20.

Hart, N.R., Stockli, D.F., Lavier, L.L., Hayman, N.W., 2017. Thermal evolution of a

This article is protected by copyright. All rights reserved. 
hyperextended rift basin, Mauléon Basin, western Pyrenees, Tectonics, 36, 1103-1128, doi:10.1002/2016TC004365.

Huet, B., Pourhiet, L.L., Labrousse, L., Burov, E., Jolivet, L., 2011. Post-orogenic extension and metamorphic core complexes in a heterogeneous crust: the role of crustal layering inherited from collision. Application to the Cyclades (Aegean domain). Geophys. J. Int. 184, 611-625. https://doi.org/10.1111/j.1365-246X.2010.04849.x

Huismans, R.S., Beaumont, C., 2003. Symmetric and asymmetric lithospheric extension: Relative effects of frictional-plastic and viscous strain softening. J. Geophys. Res. Solid Earth 108. https://doi.org/10.1029/2002JB002026

James, V., Canérot, J., 1999. Diapirisme et structuration post-triasique des Pyrénées occidentale et de l'Aquitaine méridionale (France). Eclogae Geologicae Helvetiae 92, 6372.

Jammes, S., Manatschal, G., Lavier, L., Masini, E., 2009. Tectonosedimentary evolution related to extreme crustal thinning ahead of a propagating ocean: Example of the western Pyrenees. Tectonics 28. doi:10.1029/2008TC002406

Jammes, S., Lavier, L., Manatschal, G., 2010a. Extreme crustal thinning in the Bay of Biscay and the Western Pyrenees: From observations to modeling. Geochem. Geophys. Geosystems 11. https://doi.org/10.1029/2010GC003218

Jammes, S., Lavier, L.L., 2016. The effect of bimineralic composition on extensional processes at lithospheric scale. Geochem. Geophys. Geosystems 17, 3375-3392. https://doi.org/10.1002/2016GC006399

Jammes, S., Manatschal, G., Lavier, L., 2010b. Interaction between prerift salt and detachment faulting in hyperextended rift systems: The example of the Parentis and Mauléon basins (Bay of Biscay and western Pyrenees). AAPG Bull. 94, 957-975. https://doi.org/10.1306/12090909116

Kirby, S.H., 1983. Rheology of the lithosphere. Rev. Geophys. 21, 1458-1487. https://doi.org/10.1029/RG021i006p01458

Kirby, S.H., Kronenberg, A.K., 1987. Rheology of the lithosphere: Selected topics. Rev. Geophys. 25, 1219-1244. https://doi.org/10.1029/RG025i006p01219

Lagabrielle, Y., Bodinier, J.-L., 2008. Submarine reworking of exhumed subcontinental mantle rocks: field evidence from the Lherz peridotites, French Pyrenees. Terra Nova 20,11-21. https://doi.org/10.1111/j.1365-3121.2007.00781.x

Lagabrielle, Y., Clerc, C., Vauchez, A., Lahfid, A., Labaume, P., Azambre, B., Fourcade, S., Dautria, J.-M., 2016. Very high geothermal gradient during mantle exhumation recorded in mylonitic marbles and carbonate breccias from a Mesozoic Pyrenean palaeomargin (Lherz area, North Pyrenean Zone, France). Comptes Rendus Geosci., From rifting to mountain building: the Pyrenean Belt 348, 290-300.

https://doi.org/10.1016/j.crte.2015.11.004

Lagabrielle, Y., Labaume, P., Blanquat, M. de S., 2010. Mantle exhumation, crustal denudation, and gravity tectonics during Cretaceous rifting in the Pyrenean realm (SW Europe): Insights from the geological setting of the lherzolite bodies. Tectonics 29.

This article is protected by copyright. All rights reserved. 
https://doi.org/10.1029/2009TC002588

Le Roux, V., Bodinier, J.-L., Tommasi, A., Alard, O., Dautria, J.-M., Vauchez, A., Riches, A.J.V., 2007. The Lherz spinel lherzolite: Refertilized rather than pristine mantle. Earth Planet. Sci. Lett. 259, 599-612. https://doi.org/10.1016/j.epsl.2007.05.026

Liao, J., Gerya, T., 2014. Influence of lithospheric mantle stratification on craton extension: Insight from two-dimensional thermo-mechanical modeling. Tectonophysics, Observational and Modelling perspectives on the Mechanical properties of the Lithosphere 631, 50-64. https://doi.org/10.1016/j.tecto.2014.01.020

Masini, E., Manatschal, G., Tugend, J., Mohn, G., Flament, J.-M., 2014. The tectonosedimentary evolution of a hyper-extended rift basin: the example of the ArzacqMauléon rift system (Western Pyrenees, SW France). Int. J. Earth Sci. 103, 1569-1596. https://doi.org/10.1007/s00531-014-1023-8

Mauduit, T., Gaullier, V., Brun, J.P., Guerin, G., 1997a. On the asymmetry of turtle-back growth anticlines. Mar. Pet. Geol. 14, 763-771. https://doi.org/10.1016/S02648172(97)00053-6

Mauduit, T., Guerin, G., Brun, J. P., Lecanu, H., 1997b. Raft tectonics: The effects of basal slope value and sedimentation rate on progressive extension: J Struct Geol 19, 12191230.

McClay, K., Muñoz, J.-A., García-Senz, J., 2004. Extensional salt tectonics in a contractional orogen: A newly identified tectonic event in the Spanish Pyrenees. Geology 32, 737-740. https://doi.org/10.1130/G20565.1

McClay, K.R., White, M.J., 1995. Analogue modelling of orthogonal and oblique rifting. Mar. Pet. Geol. 12, 137-151. https://doi.org/10.1016/0264-8172(95)92835-K

Mohriak, W.U., Szatmari, P., 2001. Salt tectonics and sedimentation along Atlantic margins: Insights from seismic interpretation and physical models. Geological Society of America Memoir 193, 131-151.

Mouthereau, F., Filleaudeau, P.-Y., Vacherat, A., Pik, R., Lacombe, O., Fellin, M.G., Castelltort, S., Christophoul, F., Masini, E., 2014. Placing limits to shortening evolution in the Pyrenees: Role of margin architecture and implications for the Iberia/Europe convergence. Tectonics 33, 2283-2314. https://doi.org/10.1002/2014TC003663

Nagel, T.J., Buck, W.R., 2004. Symmetric alternative to asymmetric rifting models. Geology 32, 937-940. http://dx.doi.org/10.1130/G20785.1.

Naliboff, J., Buiter, S.J.H., 2015. Rift reactivation and migration during multiphase extension. Earth Planet. Sci. Lett. 421, 58-67. https://doi.org/10.1016/j.epsl.2015.03.050

Naliboff, J.B., Buiter, S.J.H., Péron-Pinvidic, G., Osmundsen, P.T., Tetreault, J., 2017. Complex fault interaction controls continental rifting. Nat. Commun. 8, 1179. https://doi.org/10.1038/s41467-017-00904-x

Nalpas, T., Brun, J.-P., 1993. Salt flow and diapirism related to extension at crustal scale. 
Tectonophysics 228, 349-362. https://doi.org/10.1016/0040-1951(93)90348-N

Nestola, Y., Storti, F., Cavozzi, C., 2015. Strain rate-dependent lithosphere rifting and necking architectures in analog experiments, J. Geophys. Res. Solid Earth, 120, https://doi.org/10.1002/2014JB011623.

Olivet, J.-L., 1996. La cinématique de la plaque Ibérie. Bull Cent Rech Explor. Elf Aquitaine 20, 131-195.

Ortí, F., Pérez-López, A., Salvany, J.M., 2017. Triassic evaporites of Iberia: Sedimentological and palaeogeographical implications for the western Neotethys evolution during the Middle Triassic-Earliest Jurassic. Palaeogeogr. Palaeoclimatol. Palaeoecol. 471,157-180. https://doi.org/10.1016/j.palaeo.2017.01.025

Peron-Pinvidic, G., Manatschal, G., Osmundsen, P.T., 2013. Structural comparison of archetypal Atlantic rifted margins: A review of observations and concepts. Mar. Pet. Geol. 43, 21-47. https://doi.org/10.1016/j.marpetgeo.2013.02.002

Picazo, S., Müntener, O., Manatschal, G., Bauville, A., Karner, G., Johnson, C., 2016. Mapping the nature of mantle domains in Western and Central Europe based on clinopyroxene and spinel chemistry: Evidence for mantle modification during an extensional cycle. Lithos 266, 233-263. https://doi.org/10.1016/j.lithos.2016.08.029

Rey, P.F., Teyssier, C., Whitney, D.L., 2009. Extension rates, crustal melting, and core complex dynamics. Geology 37, 391-394. https://doi.org/10.1130/G25460A.1

Roca, E., Muñoz, J.A., Ferrer, O., Ellouz, N., 2011. The role of the Bay of Biscay Mesozoic extensional structure in the configuration of the Pyrenean orogen: Constraints from the MARCONI deep seismic reflection survey. Tectonics 30.

https://doi.org/10.1029/2010TC002735

Saint Blanquat, M., 1993. La faille normale ductile du massif du Saint Barthélémy: Evolution hercynienne des massifs nord-pyrénéens catazonaux considérée du point de vue de leur histoire thermique. Geodin. Acta 6(1), 59-77.

Saspiturry, N., Cochelin, B., Razin, P., Leleu, S., Lemirre, B., Issautier, B., Serrano, O., Lasseur, E., Baudin, T., 2019. Tectono-sedimentary evolution of a rift-system controlled by Permian post orogenic extension and MCC formation (Bidarray Basin and Ursuya dome, Western Pyrenees), accepted.

Saura, E., Oró, L.A. i, Teixell, A., Vergés, J., 2016. Rising and falling diapirs, shifting depocenters, and flap overturning in the Cretaceous Sopeira and Sant Gervàs subbasins (Ribagorça Basin, southern Pyrenees). Tectonics 35, 638-662.

https://doi.org/10.1002/2015TC004001

Schmeling, H., Wallner, H., 2012. Magmatic lithospheric heating and weakening during continental rifting: A simple scaling law, a 2-D thermomechanical rifting model and the East African Rift System. Geochem. Geophys. Geosystems 13.

https://doi.org/10.1029/2012GC004178

Sibuet, J.-C., Srivastava, S.P., Spakman, W., 2004. Pyrenean orogeny and plate kinematics. J. Geophys. Res. Solid Earth 109. https://doi.org/10.1029/2003JB002514

This article is protected by copyright. All rights reserved. 
Souche, A., Dabrowski, M., Andersen, T.B., 2014. Modeling thermal convection in supradetachment basins: example from western Norway. Geofluids 14, 58-74.

Souquet, P., 1985. The Black Flysch (Albian-early Cenomanian) from the Pyrenees. Cent. Rech. Explor.-Prod. Elf- Aquitaine 9, 183-252.

Stewart S. A., Coward, M. P., 1995. Synthesis of Salt Tectonics in the Southern North Sea, UK, Mar Petrol Geol 12, 457-475. http://dx.doi.org/10.1016/0264-8172(95)91502-G

Teixell, A., Labaume, P., Lagabrielle, Y., 2016. The crustal evolution of the west-central Pyrenees revisited: Inferences from a new kinematic scenario. Comptes Rendus Geosci., From rifting to mountain building: the Pyrenean Belt 348, 257-267.

https://doi.org/10.1016/j.crte.2015.10.010

Tetreault, J.L., Buiter, S.J.H., 2018. The influence of extension rate and crustal rheology on the evolution of passive margins from rifting to break-up. Tectonophysics, Understanding geological processes through modelling - A Memorial Volume honouring Evgenii Burov 746, 155-172. https://doi.org/10.1016/j.tecto.2017.08.029

Tirel, C., Brun, J.P., Burov, E., Sokoutis, D., 2004. Numerical and analogue modelling of metamorphic core complex development. Boll. Geofis. Teor. E Appl. 45, 156-160.

Tron, V., Brun, J.-P., 1991. Experiments on oblique rifting in brittle-ductile systems. Tectonophysics, Experimental and Numerical Modelling of Continental Deformation 188, 71-84. https://doi.org/10.1016/0040-1951(91)90315-J

Tugend, J., Manatschal, G., Kusznir, N.J., Masini, E., Mohn, G., Thinon, I., 2014. Formation and deformation of hyperextended rift systems: Insights from rift domain mapping in the Bay of Biscay-Pyrenees. Tectonics 33, 1239-1276.

https://doi.org/10.1002/2014TC003529

Vacherat, A., Mouthereau, F., Pik, R., Bellahsen, N., Gautheron, C., Bernet, M., Daudet, M., Balansa, J., Tibari, B., Pinna Jamme, R., Radal, J., 2016. Rift-to-collision transition recorded by tectono-thermal evolution of the northern Pyrenees. Tectonics 35, 907933. https://doi.org/10.1002/2015TC004016

Vacherat, A., Mouthereau, F., Pik, R., Bernet, M., Gautheron, C., Masini, E., Le Pourhiet, L., Tibari, B., Lahfid, A., 2014. Thermal imprint of rift-related processes in orogens as recorded in the Pyrenees. Earth Planet. Sci. Lett. 408, 296-306.

https://doi.org/10.1016/j.epsl.2014.10.014

Vauchez, A., Clerc, C., Bestani, L., Lagabrielle, Y., Chauvet, A., Lahfid, A., Mainprice, D., 2013. Preorogenic exhumation of the North Pyrenean Agly massif (Eastern PyreneesFrance). Tectonics 32, 95-106. https://doi.org/10.1002/tect.20015

Vissers, R.L.M., 1992. Variscan extension in the Pyrenees. Tectonics 11(6), 1369-1384.

Weijermars, R., Jackson, M.P.A., Vendeville, B., 1993. Rheological and tectonic modeling of salt provinces. Tectonophysics 217(1-2), 143-174.

Zwaan, F., Schreurs, G., Naliboff, J., Buiter, S.J.H., 2016. Insights into the effects of oblique extension on continental rift interaction from 3D analogue and numerical models.

Tectonophysics, Special issue on Tectonics of oblique plate boundary systems 693, 239-

This article is protected by copyright. All rights reserved. 
260. https://doi.org/10.1016/j.tecto.2016.02.036

Tables

\begin{tabular}{|l|l|l|l|l|l|l|l|}
\hline & $\begin{array}{l}\rho_{\text {] }} \\
{\left[\mathrm{kg} \cdot \mathrm{m}^{-3}\right]}\end{array}$ & $k\left[\mathrm{~W}^{\left.-\mathrm{m}^{-1} \cdot \mathrm{K}^{-1}\right]}\right.$ & $Q_{r}\left[\mathrm{~W} \cdot \mathrm{m}^{-3}\right]$ & $\phi$ & $A\left[\mathrm{~Pa}^{-\mathrm{n}} \cdot \mathrm{s}^{-1}\right]$ & $n$ & $Q\left[\mathrm{~J} \cdot \mathrm{mol}^{-1}\right]$ \\
\hline $\begin{array}{l}\text { Sediments } \\
\text { quet } \\
\text { quartzite) }\end{array}$ & 2700 & 2.5 & $5.0 \mathrm{e}-6$ & 20 & $5.0717 \mathrm{e}-18$ & 2.3 & $154.0 \mathrm{e}^{3}$ \\
\hline $\begin{array}{l}\text { Cover } \\
\text { (wet } \\
\text { quartzite) }\end{array}$ & 2700 & 2.5 & $1.0 \mathrm{e}-6$ & 30 & $5.0717 \mathrm{e}-18$ & 2.3 & $154.0 \mathrm{e} 3$ \\
\hline $\begin{array}{l}\text { Décollement } \\
\text { (rocksalt) }\end{array}$ & 2200 & 2.5 & $1.0 \mathrm{e}-6$ & 30 & $9.9848 \mathrm{e}-32$ & 5.3 & $102.0 \mathrm{e} 3$ \\
\hline $\begin{array}{l}\text { Basement } \\
\text { (granite) }\end{array}$ & 2800 & 2.0 & $1.0 \mathrm{e}-6$ & 30 & $3.1623 \mathrm{e}-26$ & 3.3 & $186.5 \mathrm{e} 3$ \\
\hline $\begin{array}{l}\text { Strong mantle } \\
\text { (dry olivine) }\end{array}$ & 3250 & 2.0 & $1.0 \mathrm{e}-10$ & 30 & $2.5119 \mathrm{e}-17$ & 3.5 & $532.0 \mathrm{e} 3$ \\
\hline $\begin{array}{l}\text { Weak mantle } \\
\text { (wet olivine) }\end{array}$ & 3250 & 2.0 & $1.0 \mathrm{e}-10$ & 20 & $1.9953 \mathrm{e}-21$ & 4.0 & $471.0 \mathrm{e} 3$ \\
\hline
\end{tabular}

Tab. 1. Thermal and rheological parameters used for each lithology used in the reference numerical model. The heat capacity $(C \mathrm{p})$, the compressibility $(\beta)$, thermal expansivity $(\alpha)$ and cohesion $(C)$ were respectively set to $1050 \mathrm{~J} / \mathrm{kg} / \mathrm{K}, 10^{-11} \mathrm{~Pa}^{-1}, 10^{-6} \mathrm{~K}^{-}$ 1 , and $10^{7} \mathrm{~Pa}$ for all materials. Regarding the flow laws, the strong basement, the weak basement/sediments/pre-rift cover respectively correspond to the Westerly granite (Hansen and Carter, 1983), wet quartzite (Kirby, 1983), rocksalt (Carter et al., 1993), dry olivine and wet olivine (Kirby and Kronenberg, 1987).

This article is protected by copyright. All rights reserved. 


\section{Figure captions}

Fig. 1. a) Synthetic structural map of the Pyrenees (redrawn and modified after Corre et al., 2016) with location of the main Iherzolitic bodies and distribution of the Keuper deposits. Acronyms: AB, Aulus Basin; ArM, Arize Massif; AgM, Agly Massif; BAB, Bas-Agly Basin; BB, Boucheville Basin; CaB, Camarade Basin; CoB, Cotiella Basin; Lhz, Lherz; LM, Labourd Massif; MIB, Mauléon Basin; MM, Mouthoumet Massif; MsB, Massat Basin; NB, Nalzen Basin; NPFT, North Pyrenean Frontal Thrust; NPZ, North Pyrenean Zone; Sar, Saraillé massif; SBM, Saint Barthélemy Massif; SM, Salvezines Massif; SPFB, Saint Paul de Fenouillet Basin; SPFT, South Pyrenean Frontal Thrust; SPZ, South Pyrenean Zone; TdT, Turon de la Técouère massif; TSM, Trois Seigneurs Massif; Urd, Urdach-Les Pernes massif. b) Synthetic log representing the main pre-rift lithological units and related conceptual cross-sections. c) Cross-section of the Iberia-Eurasia extensional plate boundary resulting from mid-Cretaceous rifting (after models of Lagabrielle et al., 2010; Clerc and Lagabrielle, 2014; Corre et al., 2016; and Teixell et al., 2016). The lower continental crust is only present below the proximal domain. The distal domain is dominated by ductile thinning of the continental crust that is found as thin lenses exhumed together with the mantle. The pre-rift sedimentary cover glides on top of the Keuper evaporites (i.e. décollement layer) and comes locally in direct contact with the exhumed mantle. This corresponds locally to a complete removal of the continental crust

Fig. 2. Initial and boundary conditions used in the numerical models. General setting of the model domain. Arrows indicate the directions of outflow (constant velocity, $V_{\text {out }}=0.5 \mathrm{~cm} / \mathrm{y}$ ) and inflow (constant velocity, $V_{\text {in }} 1.0=\mathrm{cm} / \mathrm{y}$ ). An initial temperature perturbation is set at coordinates $x=10 \mathrm{~km}$ and $y=-45 \mathrm{~km}$. White lines correspond to isotherms ( $200{ }^{\circ} \mathrm{C}$ spacing). The initial Moho temperature is $480^{\circ} \mathrm{C}$ and the décollement layer thickness is $1.5 \mathrm{~km}$.

Fig. 3. Lithological types and strain fields evolution of the reference model. Results are depicted at four time steps: a) 5.0 My, b) 7.5 My, c) 10.0 My and d) $15.5 \mathrm{My}$. White lines depict isotherms (200 ${ }^{\circ} \mathrm{C}$ spacing). The gray boxes on panels a) and d) correspond to the figure enlargements depicted in Figs. 5 and Fig. 9.

Fig. 4. Respective contributions of ductile (left) and frictional (right) strain rates for the reference model at the same time steps than in Fig. 3. White lines correspond to lithological contours. Color maps are taken from Scientific Colour-Maps (Crameri, 2018).

Fig. 5. Detailed structure of the rifted margin. Panel a) depicts lithological types and isotherms. Same color palette than in Fig. 2. Panel b) corresponds to the finite strain. White lines correspond to lithological contours.

Fig. 6. Effects of décollement thickness. Four thicknesses were considered, $0.0 \mathrm{~m} \mathrm{(a)}, 750 \mathrm{~m}$ (b), $1.5 \mathrm{~km}$ (c) and $3.0 \mathrm{~km}$ (d). Lithological types: same color palette as in Fig. 2. White lines correspond to isotherms $\left(200{ }^{\circ} \mathrm{C}\right.$ spacing). Extension rate: $1 \mathrm{~cm} / \mathrm{y}$.

Fig. 7. Effects of variations in rheological models $(a, b)$, initial thermal conditions (c, d) and extension rate $(e, f)$. Same color palette as in Fig. 2 . White lines correspond to isotherms (200 ${ }^{\circ} \mathrm{C}$ spacing).

This article is protected by copyright. All rights reserved. 
Fig. 8. Effects of a pre-rift salt décollement on the thermal regime of pre-rift and syn-rift sediments. Spatial distribution of maximum temperature (in time) (a) in the pre-rift sediments, (b) syn-rift sediments. (c) Relative temperature variation from the onset of the simulation up to current model time. (d) Evolution of the maximum temperature (measured through time in the syn-rift and pre-rift sediments) for models with and without cover/basement décollement.

Fig. 9. Relation between salt tectonic structures and displacements in one of the rift shoulder domains. a) Pattern of normal faulting related to raft formation in the pre-rift cover with associated syn-kinematic basins and diapiric salt structures. Same color palette than in Fig. 2. b) Velocity field: Vectors are plotted with reference to rift axis (to the left). Pale brown and pale blue domains correspond to displacements away and toward rift axis, respectively. White lines correspond to the contours of lithology for the domains shown in (a).

Fig. 10. Comparison between structures in the model and those identified in the North Pyrenean Zone. a) Line-drawing of the reference model at $12.5 \mathrm{Myr}$ (as in Fig. 3). b) Sketches of five types of structures identified in the NPZ. 1) Décollement and basal truncation of prerift cover block in fault-bounded basins of the proximal part (South Mouthoumet massif). 2) Rollover-type structures above the Keuper salt formations in the proximal domain (Cotiella basin). 3) Lenses of continental crust (basement) exhumed together with mantle rocks in the distal domain, beneath the pre-rift cover. The syn-rift cover is locally in direct contact with the exhumed mantle what implies a complete removal of the basement. 4) Large rigid blocks faulted and tilted above the ductilely deforming continental crust during mantle exhumation (e.g. North Pyrenean Massifs of Trois Seigneurs, Saint Barthelemy, Agly). 5) Synextensional diapir that emplaced during deposition of syn-rift cover) (e.g. Basins of St Paul de Fenouillet and Quillan).

This article is protected by copyright. All rights reserved. 


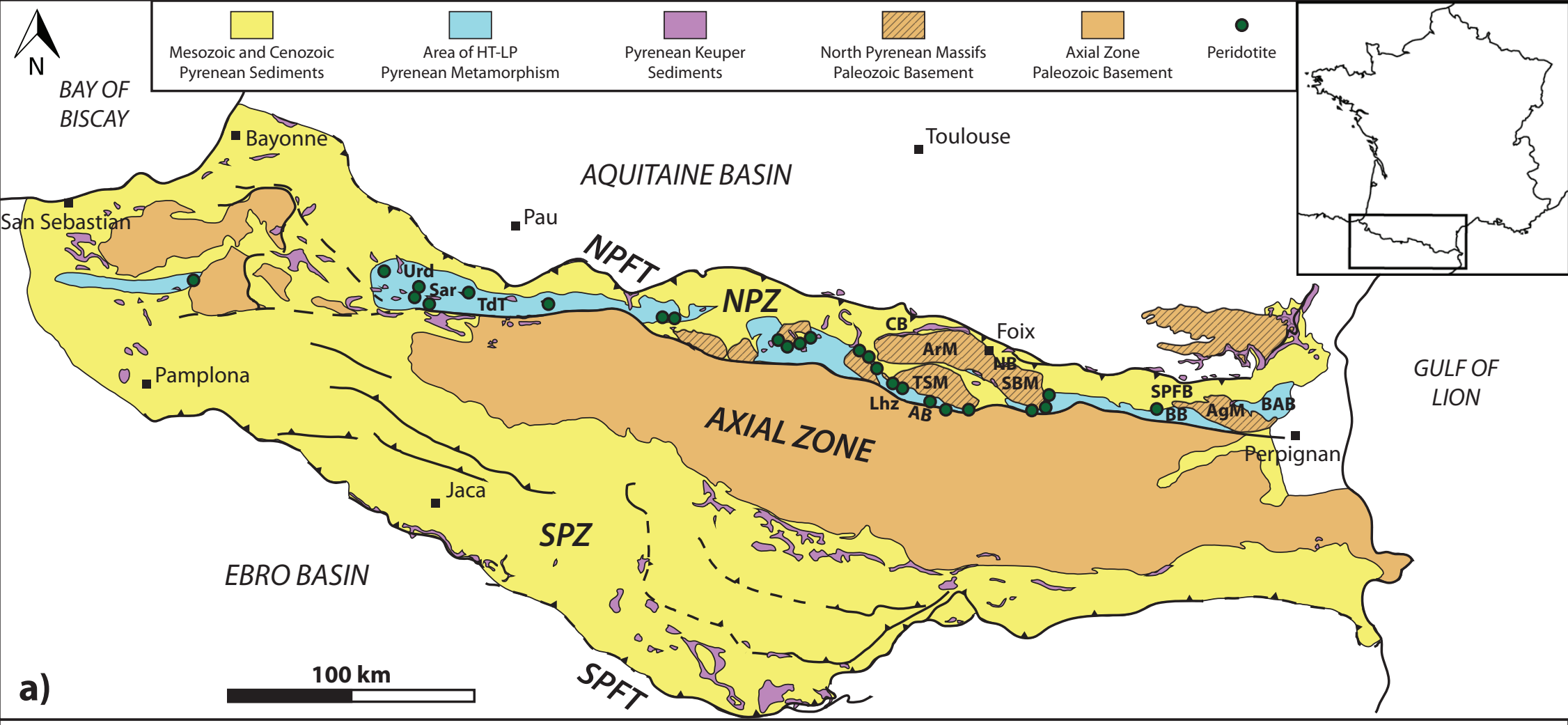

a)
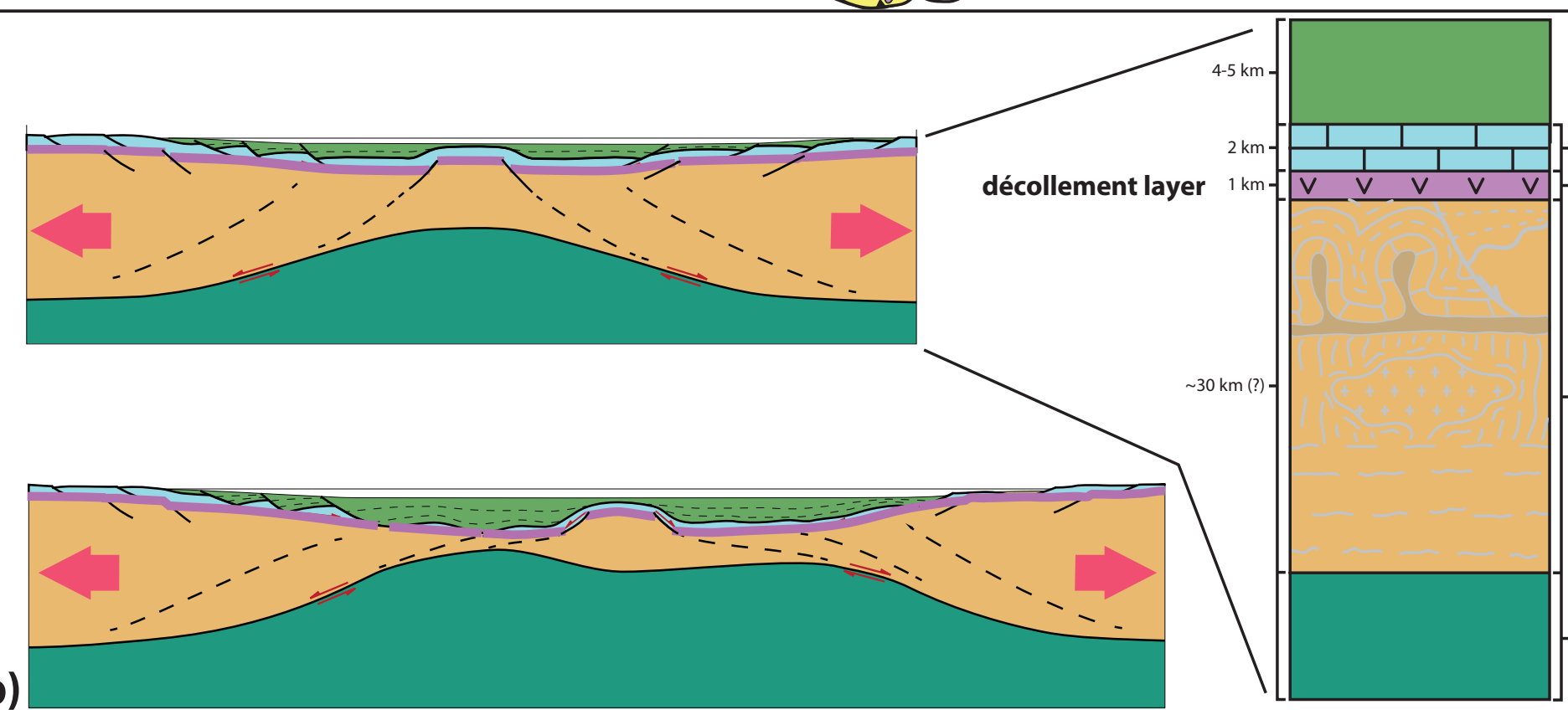

Syn-rift cover Pre-rift cover
(Lias-Neocomian) (Keuper evaporites)

b)

North Pyrenean Camarade B., Bas Agly B.,

Mauléon B., Aulus B., Boucheville B., etc...

Massif St Paul de F. B., Quillan B., etc...

Crustal basement

Lithospheric mantle

$\mathrm{S}$

$$
\begin{aligned}
& S \\
& \hline= \\
& \text { c) }
\end{aligned}
$$
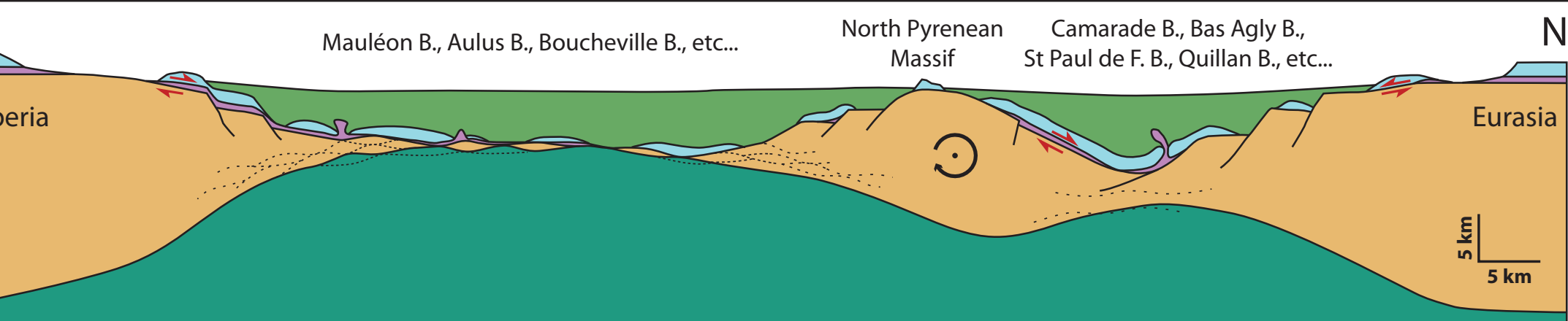

Synthetic reconstruction of the Western, central and Eastern NPZ after Clerc et al., 2015 and Teixell et al., 2016

C) $\square$ Syn-rift (Albian/Cenomanian)

Pre-rift (Lias-Neocomian) - Keuper evaporites (late Triassic) in pink

$\square$ Continental Crust

Mantle 


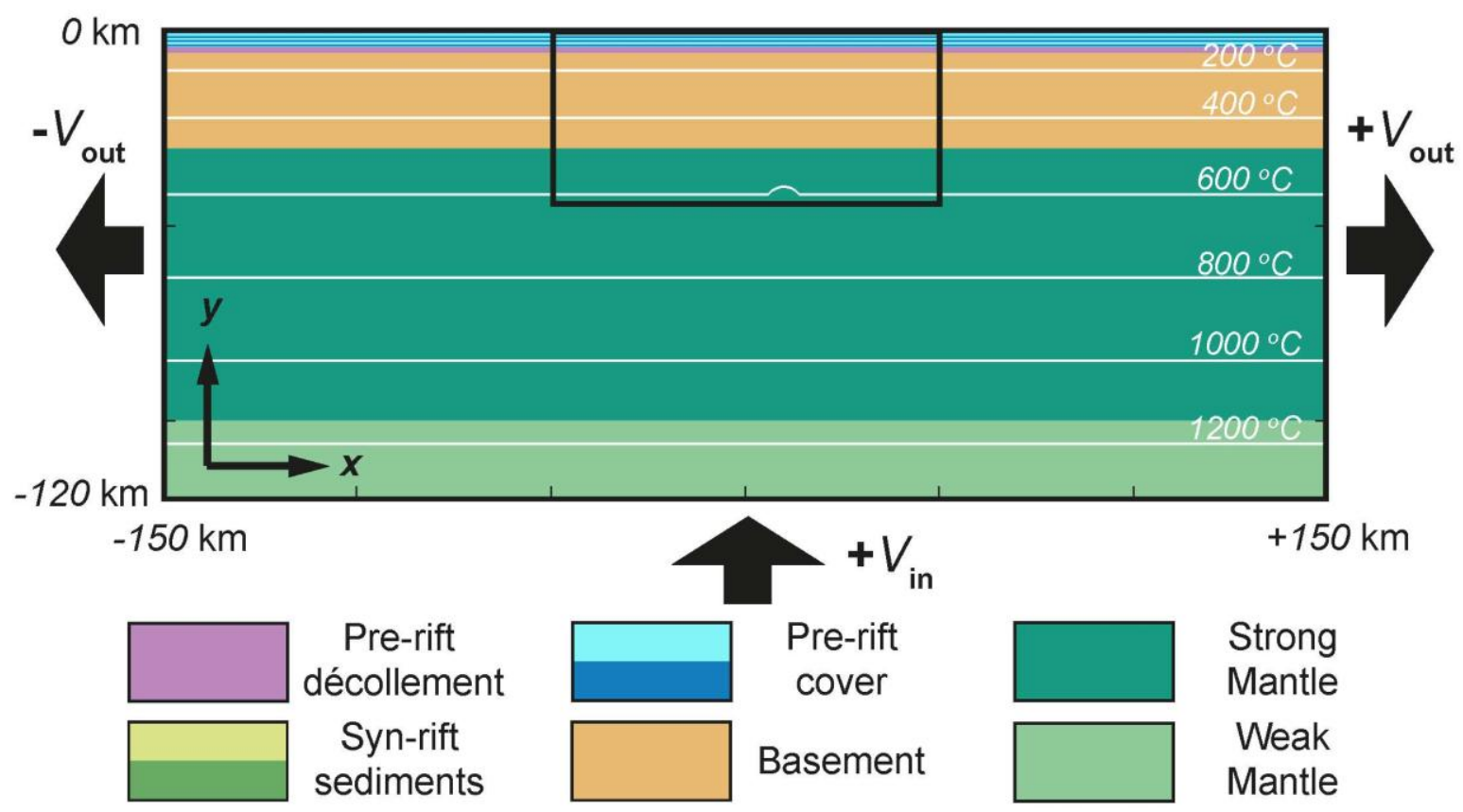

This article is protected by copyright. All rights reserved. 


\section{Reference model: Lithologies}

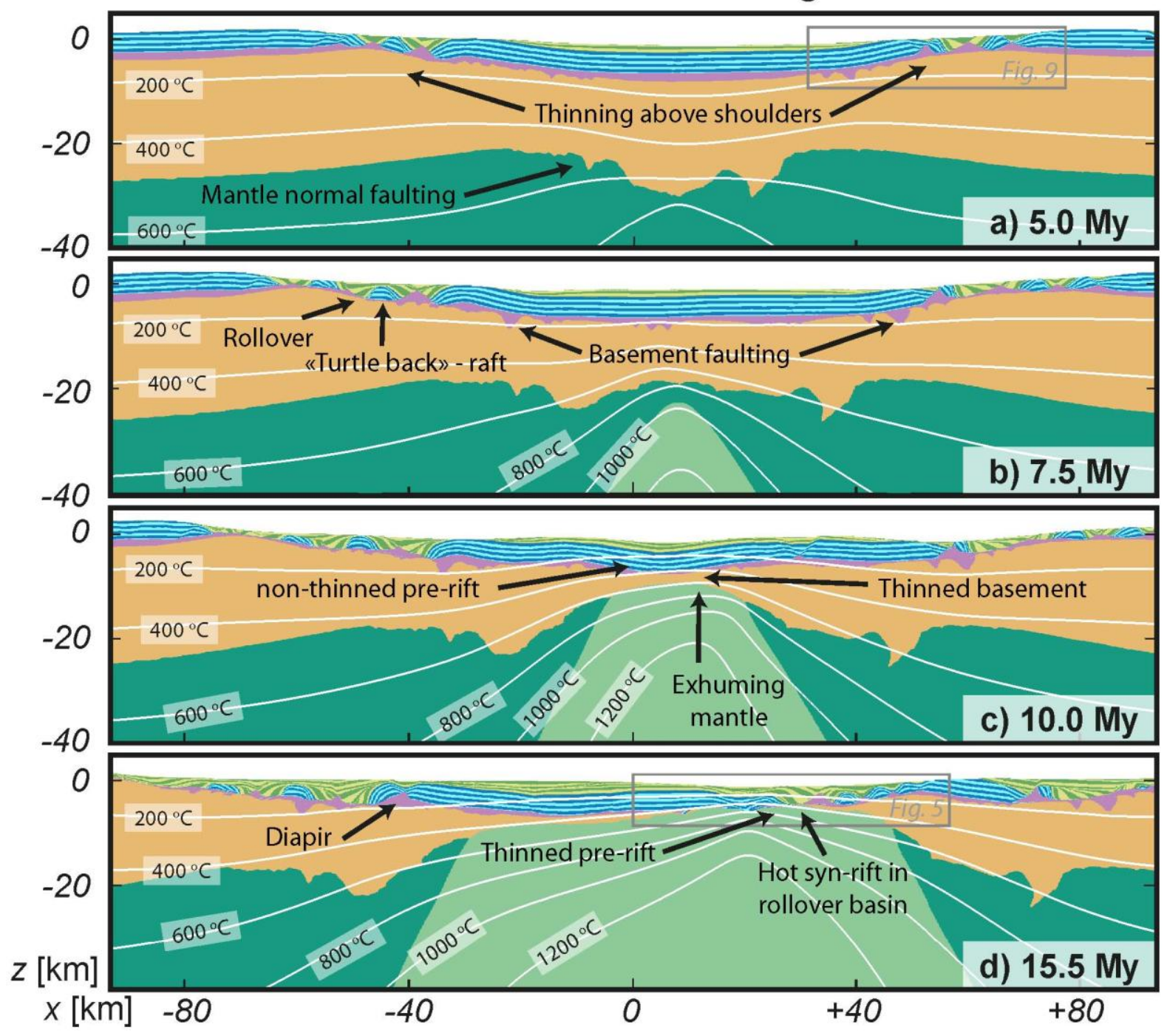

This article is protected by copyright. All rights reserved. 


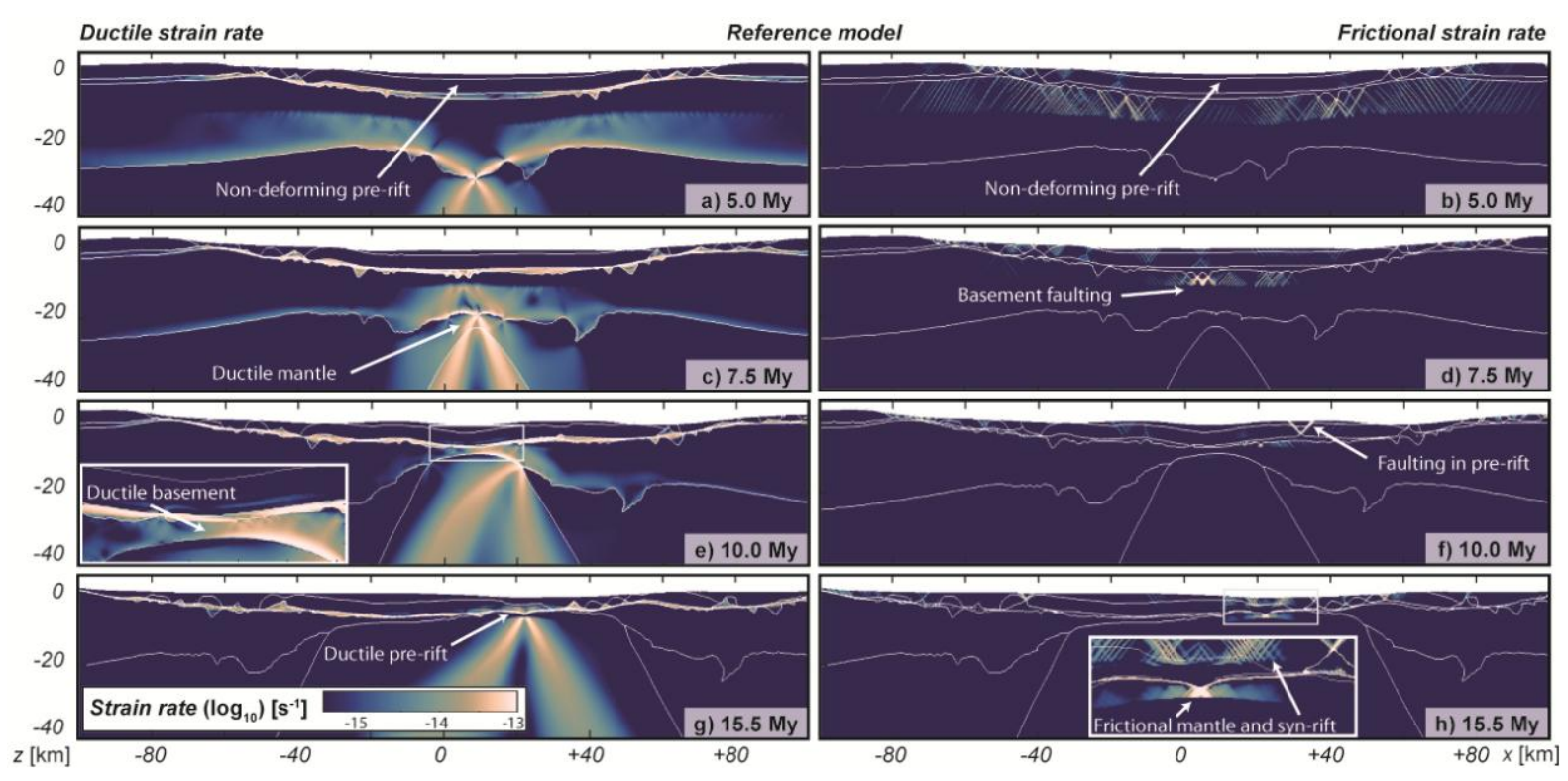

This article is protected by copyright. All rights reserved. 

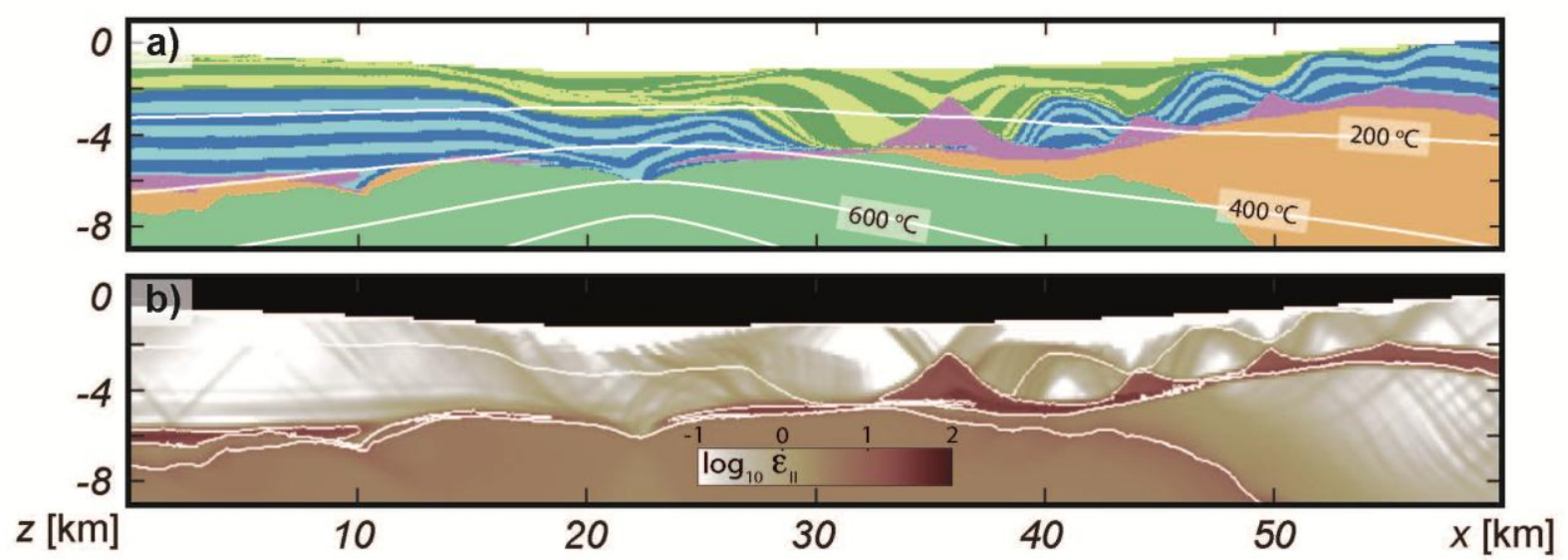

This article is protected by copyright. All rights reserved. 

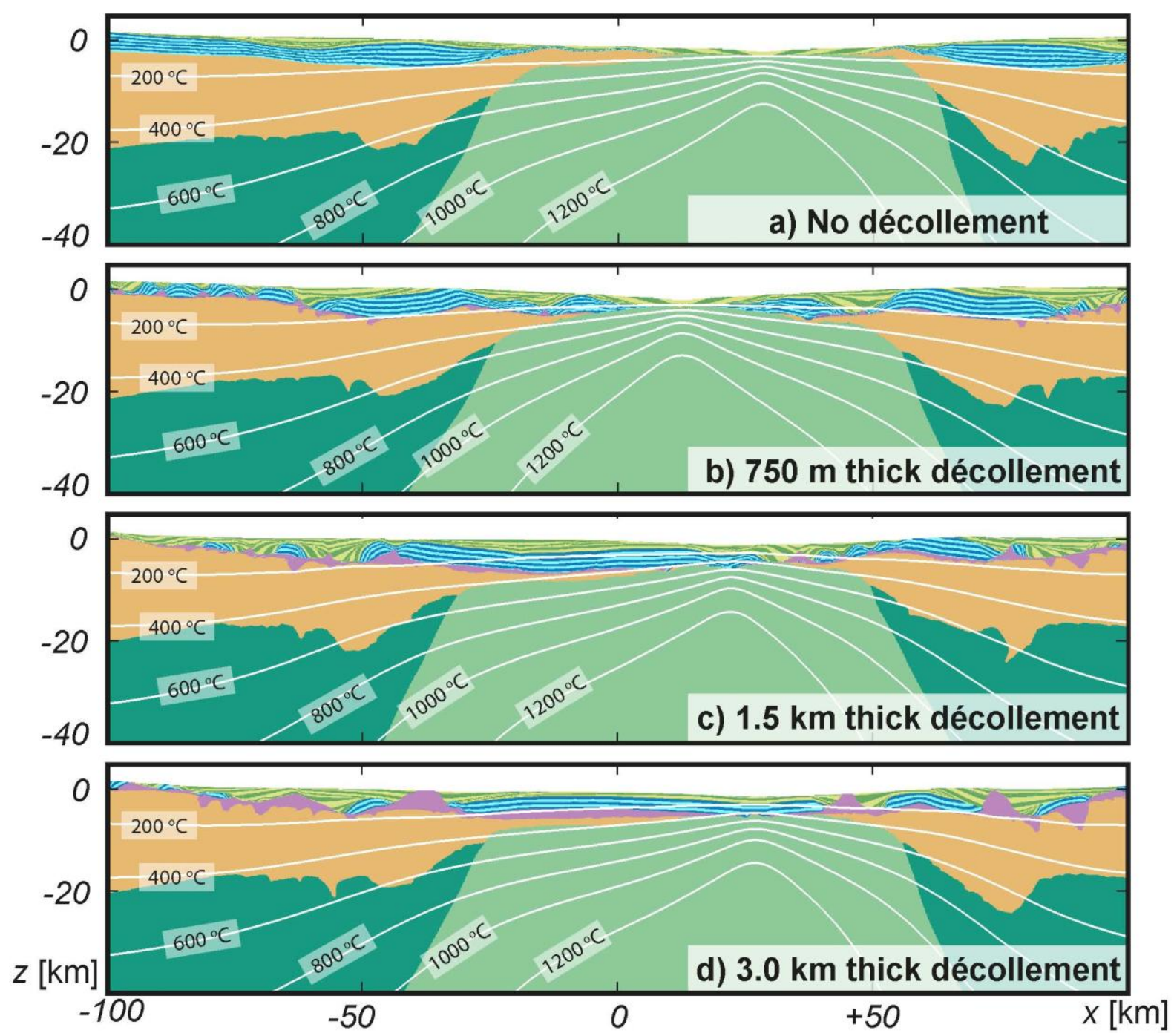
Parametric study: Lithologies after $50 \%$ stretching

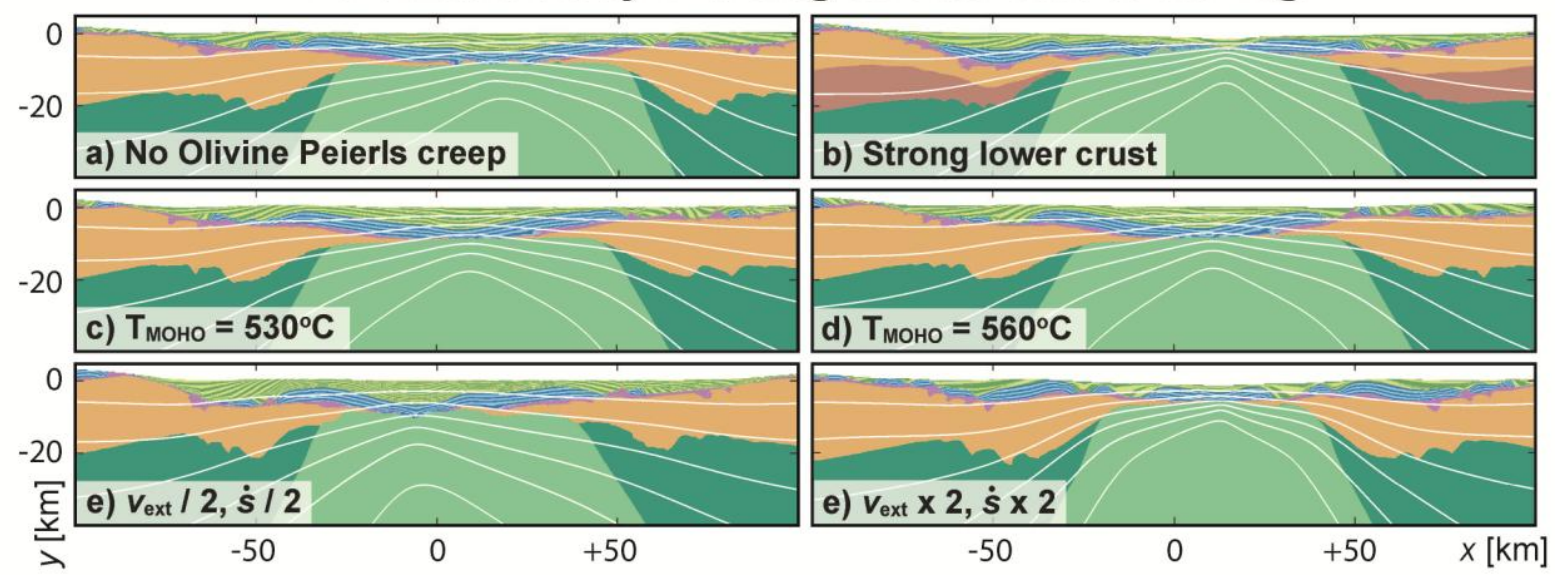

This article is protected by copyright. All rights reserved. 

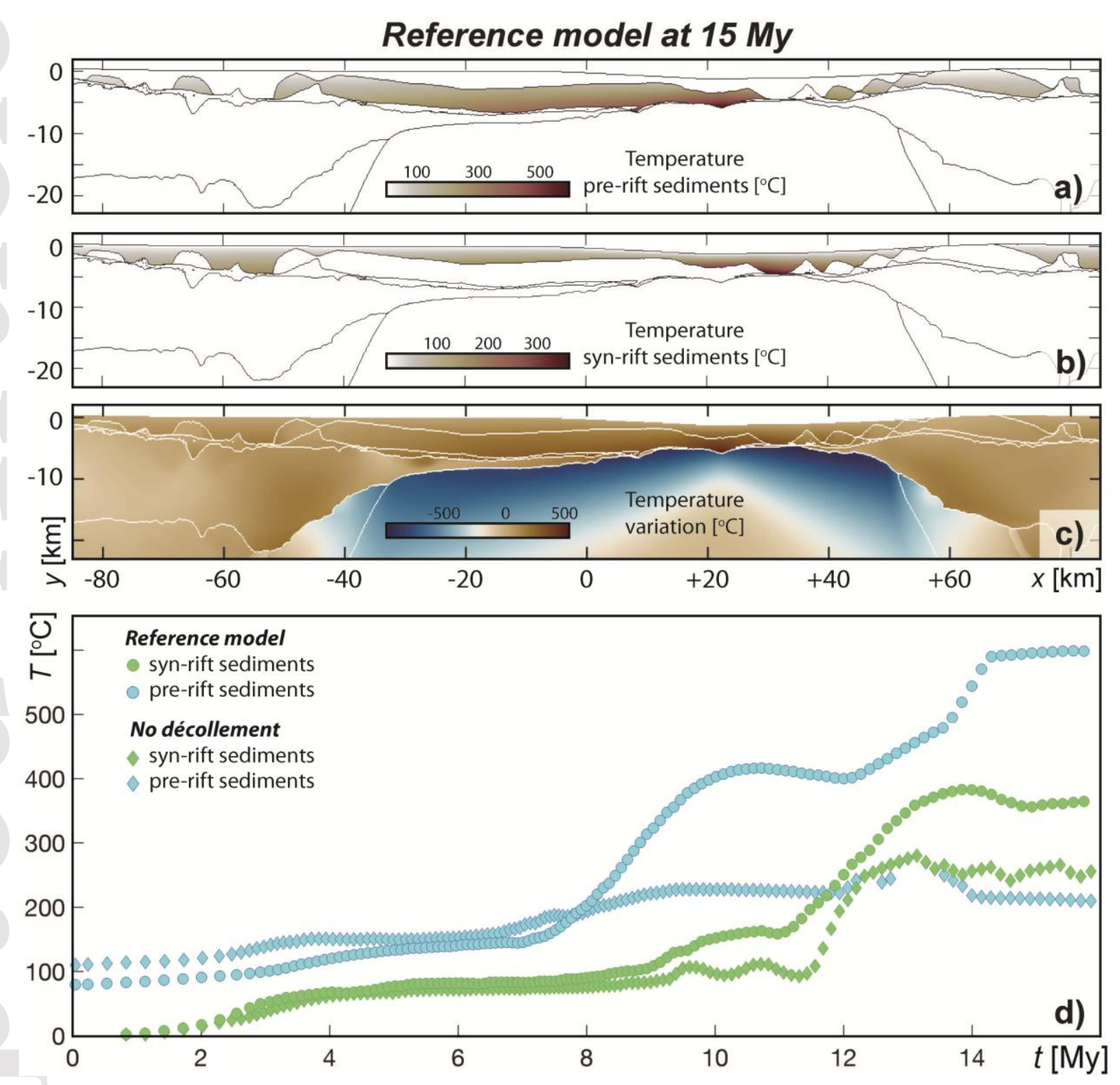

This article is protected by copyright. All rights reserved. 


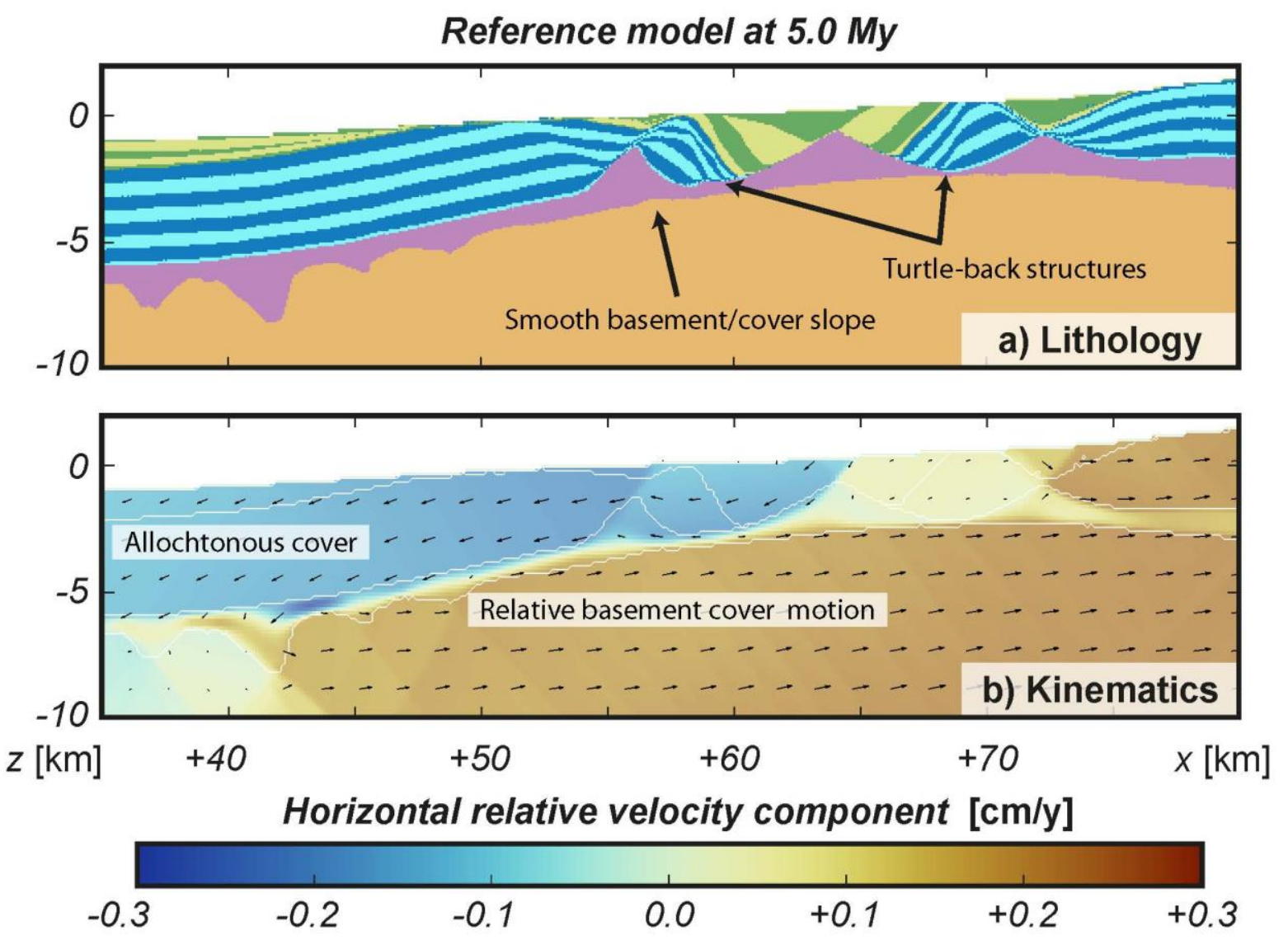

This article is protected by copyright. All rights reserved. 


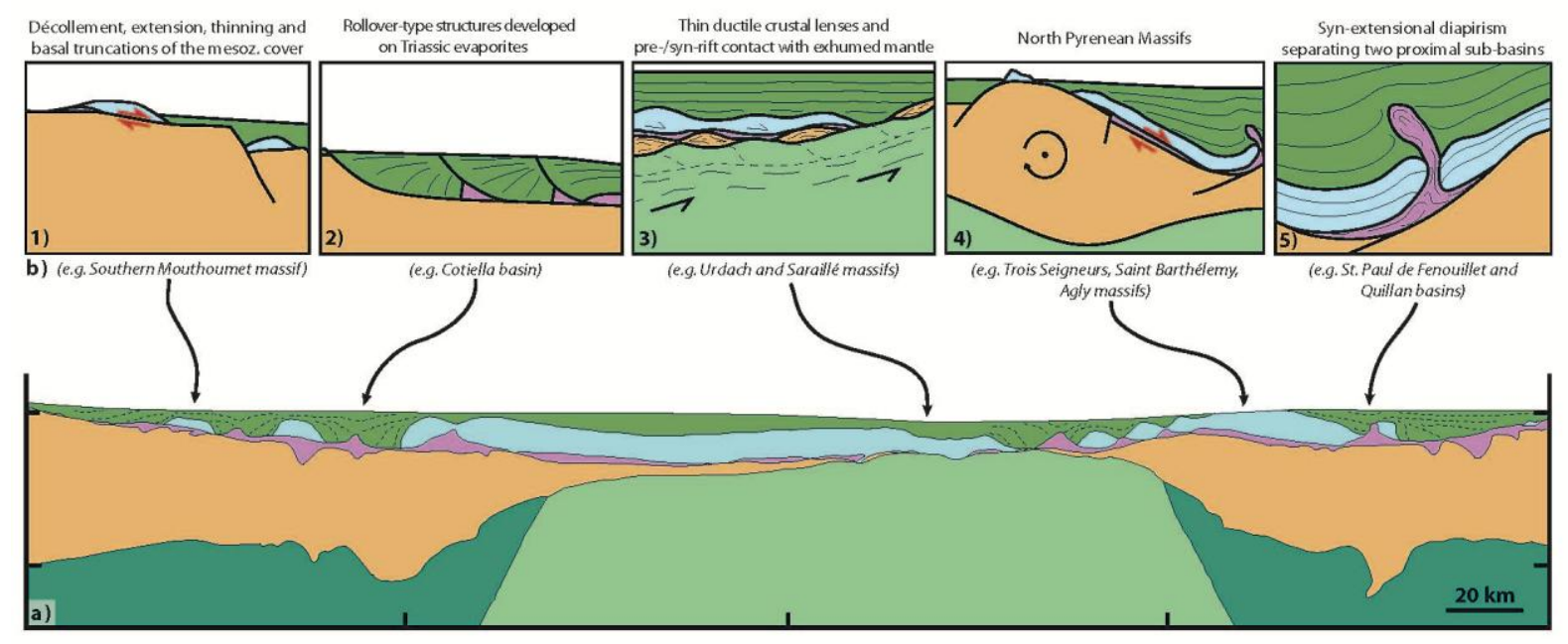

This article is protected by copyright. All rights reserved. 


\section{Numerical modelling of syn-rift salt tectonics and mantle exhumation in the Cretaceous Pyrenean Rift}

Thibault Duretz ${ }^{1,2}$, Riccardo Asti ${ }^{1}$, Yves Lagabrielle $^{1}$, Jean-Pierre Brun ${ }^{1}$, Anthony Jourdon ${ }^{3}$, Camille Clerc $^{4}$, Benjamin Corre ${ }^{1}$

5. Univ Rennes, CNRS, Géosciences Rennes UMR 6118, F-35000 Rennes, France

6. ISTE, FGSE, University of Lausanne, CH-1025, Lausanne, Switzerland

7. GET, Observatoire Midi Pyrenées, Toulouse, France

8. LIVE, University of New Caledonia, Nouméa, France

\section{Appendix: Numerical modeling}

The presented thermo-mechanical models were obtained by solving the conservation equation for a steady state momentum, transient heat conservation and incompressible mass conservation equations:

$$
\begin{gathered}
\frac{\partial \tau_{i j}}{\partial x_{j}}-\frac{\partial P}{\partial x_{i}}=-\rho g_{i} \\
\rho c_{p} \frac{D T}{D t}=\frac{\partial}{\partial x_{i}}\left(k \frac{\partial T}{\partial x_{i}}\right)+Q_{r}+\tau_{i j} \dot{\epsilon}_{i j} \\
\frac{\partial v_{i}}{\partial x_{i}}=0
\end{gathered}
$$

where $v$ is the velocity vector, $T$ is the temperature, $k$ is the thermal conductivity, $\rho$ is the density, $c_{p}$ is the heat capacity, $Q_{r}$ is the radiogenic heat production, $\tau$ is the deviatoric stress tensor, $\dot{\varepsilon}$ is the deviatoric strain rate tensor, $P$ is the pressure and $g$ is the gravity acceleration vector. The term $\tau_{i j} \dot{\epsilon}_{i j}$ describes the production of heat by visco-plastic dissipation (shear heating).

The density field evolves according the following equation of state:

$$
\rho=\rho_{0}\left(1-\alpha\left(T-T_{0}\right)\right)\left(1+\beta\left(P-P_{0}\right)\right)
$$

where $\rho_{0}$ is the reference density, $\alpha$ is the thermal expansivity, $\beta$ is the compressibility, $T_{0}$ and $P_{0}$ are the reference temperature and pressure which were respectively set to 0 $\mathrm{C}$ and $10^{5} \mathrm{~Pa}$.

The effective viscosity $(\eta)$ relates the deviator stress and strain rate tensor in the following fashion:

This article is protected by copyright. All rights reserved. 


$$
\tau_{i j}=2 \eta \dot{\epsilon}_{i j}=\left(\frac{1}{\eta^{v}}+\frac{1}{\eta^{e}}+\frac{1}{\eta^{p}}\right)^{-1} \dot{\epsilon}_{i j}
$$

and is computed in order to satisfy a visco-elasto-plastic rheological model:

$$
\dot{\epsilon}_{i j}=\dot{\epsilon}_{i j}^{v}+\dot{\epsilon}_{i j}^{e}+\dot{\epsilon}_{i j}^{p} \text { where } \dot{\epsilon}_{i j}^{v}=\dot{\epsilon}_{i j}{ }^{d i s}+\dot{\epsilon}_{i j}{ }^{\text {Peierls }}
$$

where the $v, e$, and $p$ superscripts correspond to viscous, elastic and plastic portions and the surperscripts dis and Peielrs refers to the dislocation and Peierls creep mechanisms.

The viscous strain rate is computed as:

$$
\dot{\epsilon}_{i j}{ }^{d i s}=\dot{\epsilon}_{I I} \text { dis } \frac{\tau_{i j}}{\tau_{I I}}=A\left(2 f e^{\frac{Q}{n R T}}\right)^{-n} \tau^{n} \frac{\tau_{i j}}{\tau_{I I}}
$$

where $A$ is a pre-factor, $Q$ is the activation energy, $n$ is the stress exponent $R$ is the universal gas constant and $f$ is a correction factor (Schmalholz and Fletcher, 2011). The subscripts II stand for the square root of the second tensor invariant. The elastic strain rate is written as:

$$
\dot{\epsilon}_{i j}^{e}=\frac{\dot{\tau}_{i j}}{2 G} \frac{\tau_{i j}}{\tau_{I I}}
$$

where $G$ is the shear modulus (set to $10^{10} \mathrm{~Pa}$ ).

The plastic strain rate takes the form of:

$$
\dot{\epsilon}_{i j}^{p}=\dot{\epsilon}_{I I} p \frac{\tau_{i j}}{\tau_{I I}} \text { for } \dot{\epsilon}_{I I}^{p}=\dot{\epsilon}_{I I}-\frac{\dot{\tau}_{I I}}{2 G}-\frac{\tau_{y}}{2 \eta^{v}} \text { and } \tau_{y}=C \cos \varphi+P \sin \varphi
$$

where $\varphi$ is the friction angle and $C$ is the cohesion. The friction angle is set to $20^{\circ}$ for al sediments (pre-rift and syn-rift), $25^{\circ}$ for the basement and $30^{\circ}$ for the mantle lithosphere and asthenosphere. The cohesion is set to $10 \mathrm{MPa}$ for all lithologies. We do not apply any plastic strain softening.

In the mantle lithosphere, the Peierls mechanism is also activated and its strain rate is computed as:

$$
\dot{\epsilon}_{i j}{ }^{\text {Peierls }}=\dot{\epsilon}_{I I} \text { Peierls } \frac{\tau_{i j}}{\tau_{I I}}
$$

where the effective strain rate are spelled as as:

$$
\left\{\begin{array}{c}
\dot{\epsilon}_{I I}^{\text {Peierls }}=\left(2 A^{\text {Peierls }}\right)^{-s} \frac{\tau_{i j}}{\tau_{I I}} \\
A^{\text {Peierls }}=f \gamma \sigma^{\text {Peierls }}\left(E^{\text {Peierls }} e^{\left.-\frac{(1-\gamma)^{2} Q^{\text {Peierls }}}{R T}\right)^{\frac{-1}{S}}}\right. \\
s=\frac{Q^{\text {Peierls }}}{R T}(1-\gamma)^{(q-1) q \gamma}
\end{array}\right.
$$

where the parameters $s$ is the effective stress exponent ( $T$-dependent), $Q^{\text {Peierls }}$ is the activation energy $(=540 \mathrm{~J} / \mathrm{mol}), \sigma^{\text {Peierls }}$ is the Peierls stress $\left(=8.5 .10^{9} \mathrm{~Pa}\right), E^{\text {Peierls }}$

This article is protected by copyright. All rights reserved. 
$\left(=5.7 .10^{11} \mathrm{~s}^{-1}\right), q(=2.0)$, and $\gamma(=0.1)$ (Evans and Goetze, 1979). Peierls creep stress is computed using a regularised formulation (Kameyama et al., 1999).

The temperature is kept constant at both the upper $\left(0^{\circ} \mathrm{C}\right)$ and lower boundaries $\left(1330^{\circ} \mathrm{C}\right)$ and the heat flow is set to 0 across the right and left boundaries. A constant velocity is ( $1 \mathrm{~cm} / \mathrm{y}$ of bulk extension) is imposed on the left/ right model boundaries. Inflow at the lower boundary balances the outflow imposed on the right and left sides. The shear stress is set to zero along the left, right and lower boundaries. The upper boundary is a true free surface that dynamically evolves with time and allow for a direct treatment of surface processes (Duretz et al., 2016). The equation governing the free surface evolution is written as:

$$
\frac{D h}{D t}=\frac{\partial}{\partial x_{i}}\left(D \frac{\partial h}{\partial x_{i}}\right)+\dot{s}
$$

where $h$ is the height of the free surface, $D$ is the topographic diffusivity (set $10^{-6} \mathrm{~m}^{2} \cdot \mathrm{s}^{-1}$ ) and $\dot{s}$ is the sedimentation rate (set to $0.5 \mathrm{~mm} . \mathrm{y}^{-1}$ for $h_{-}<0.0$ ). The initial temperature field is obtained by solving the steady state heat equation (neglecting shear heating) using reference thermal parameters (Tab. 1) excepted below the lithospheric mantle where the conductivity was set artificially high in order to produce a quasi-adiabatic asthenosphere. The initial topography is set to $0 \mathrm{~km}$.

The conservation equations are discretized using a finite difference/marker-in-cell technique (Gerya and Yuen, 2003). The global linearized systems of equations are solved using a direct-iterative method (Räss et al., 2017). Non-linear iterations are used at both local and global levels. At the local level, Newton iterations ensure exact partitioning of strain rates and correct evaluation of effective viscosity (Popov and Sobolev, 2008; Schmalholz and Duretz, 2017). At the global level, Picard iterations are employed to best-satisfy mechanical equilibrium equations (to an absolute tolerance of 10-6 and within a maximum of 20 iterations).

Xs

This article is protected by copyright. All rights reserved. 


\section{References:}

Duretz, T., May, D.A., Yamato, P., 2016. A free surface capturing discretization for the staggered grid finite difference scheme. Geophys J Int 204, 1518-1530.

https://doi.org/10.1093/gji/ggv526

Evans, B., Goetze, C., 1979. The temperature variation of hardness of olivine and its implication for polycrystalline yield stress. Journal of Geophysical Research: Solid Earth 84, 5505-5524. https://doi.org/10.1029/JB084iB10p05505

Gerya, T.V., Yuen, D.A., 2003. Characteristics-based marker-in-cell method with conservative finite-differences schemes for modeling geological flows with strongly variable transport properties. Physics of the Earth and Planetary Interiors 140, 293-318.

https://doi.org/10.1016/j.pepi.2003.09.006

Kameyama, M., Yuen, D.A., Karato, S.I., 1999. Thermal-mechanical effects of lowtemperature plasticity (the Peierls mechanism) on the deformation of a viscoelastic shear zone. Earth Planetary Science Letters 168, 159-172. https://doi.org/10.1016/S0012$821 \times(99) 00040-0$

Popov, A.A., Sobolev, S.V., 2008. SLIM3D: A tool for three-dimensional thermomechanical modeling of lithospheric deformation with elasto-visco-plastic rheology. Physics of the Earth and Planetary Interiors 171, 55-75. https://doi.org/10.1016/j.pepi.2008.03.007

Räss, L., Duretz, T., Podladchikov, Y.Y., Schmalholz, S.M., 2017. M2Di: Concise and efficient MATLAB 2-D Stokes solvers using the Finite Difference Method. Geochemistry, Geophysics, Geosystems 18, 755-768. https://doi.org/10.1002/2016GC006727

Schmalholz, S.M., Duretz, T., 2017. Impact of grain size evolution on necking in calcite layers deforming by combined diffusion and dislocation creep. Journal of Structural Geology 103, 37-56. https://doi.org/10.1016/j.jsg.2017.08.007

Schmalholz, S.M., Fletcher, R.C., 2011. The exponential flow law applied to necking and folding of a ductile layer. Geophysical Journal International 184, 83-89.

https://doi.org/10.1111/j.1365-246X.2010.04846.x

This article is protected by copyright. All rights reserved. 